\title{
ECONOMICS
}

\section{CHANGES IN THE OPERATIONAL EFFICIENCY OF NATIONAL OIL COMPANIES}

\author{
by \\ Peter R Hartley \\ Rice University and \\ University of Western Australia \\ Kenneth B. Medlock III \\ Rice University
}

DISCUSSION PAPER 12.12 


\title{
CHANGES IN THE OPERATIONAL EFFICIENCY OF NATIONAL OIL COMPANIES
}

\author{
Peter R Hartley \\ George and Cynthia Mitchell Professor of Economics and \\ Rice Scholar, James A. Baker III Institute for Public Policy, Rice University \\ Professor-at-Large, Institute of Advanced Studies, University of Western Australia
}

\author{
Kenneth B. Medlock III* \\ James A. Baker, III, and Susan G. Baker Fellow in Energy and Resource Economics \& \\ Deputy Director, Baker Institute Energy Forum and \\ Adjunct Professor, Economics Department, Rice University
}

\section{DISCUSSION PAPER 12.12}

\begin{abstract}
Using data on 61 oil companies from 2001-09, we examine the evolution of revenue efficiency of National Oil Companies (NOCs) and shareholder-owned oil companies (SOCs). We find that NOCs generally are less efficient than SOCs, but their efficiency increased faster over the last decade. We also find evidence that partial privatizations increase operational efficiency, and (weaker) evidence that mergers and acquisitions during the decade tended to increase the efficiency of the merging firms. Finally, we find evidence that much of the inefficiency of NOCs is consistent with the hypothesis that government ownership leads to different firm objectives.
\end{abstract}

\footnotetext{
* The authors thank James D. Coan (Research Associate \& Assistant to the Director, Baker Institute Energy Forum), Sara El Hakim (Graduate Student, Department of Economics), Jane Kliakhandler (Program Coordinator Baker Institute Energy Forum) and Likeleli Seitlheko (Graduate Student, Department of Economics) for very valuable research assistance. We also thank participants in the $4^{\text {th }}$ International Workshop on Empirical Methods in Energy Economics (EMEE) held in Dallas in July, 2011 and especially the discussant of an earlier version of this paper, Clifton Jones from Stephen F. Austin University, for valuable comments.
} 


\section{Introduction}

We examine a sample of 61 oil and gas firms to assess whether national oil companies (NOCs) were less revenue efficient than shareholder-owned oil companies (SOCs). The analysis reaffirms findings in Eller et al (2011) that NOCs tend to be less revenue efficient than SOCs. The longer time period examined in the current paper, however, also allows us to investigate how the relative efficiencies of NOCs and SOCs have changed in the last decade. This adds detail to our understanding of why some firms are less efficient than others and what types of changes may increase efficiency.

We examine revenue efficiency for several reasons. A previous theoretical paper (Hartley and Medlock (2008)) argued that revenue is a key objective for both public and private firms. That analysis also suggested, however, that political pressure is likely to force a NOC to sell products to domestic consumers at subsidized prices. Physical output measures would not necessarily capture the effect of such subsidies. In addition, almost all of the firms in the industry produce a range of products from crude oil and natural gas to refined products. The natural way to aggregate these outputs is to measure their relative value at market prices, and hence take revenue as the output measure. Finally, and perhaps of greatest practical importance, for many firms revenue figures are more readily available than physical outputs of different commodities.

We suggest that investigating the efficiency of NOCs relative to SOCs is of interest for a number of reasons. First, NOCs represent the top holders of crude oil reserves internationally. For example, in the data set we examine herein, which includes the largest oil and gas firms in the world, fully government-owned NOCs reported more than $82 \%$ of the crude oil reserves of all firms in the sample in 2009. The six largest, and eight of the top 10 largest oil reserve holders are all fully government owned NOCs. ExxonMobil is the only SOC in this group, at rank of nine in ten. As a result of their relatively large reserves, NOCs dominate global oil production and could be expected to 
do so for some time to come. ${ }^{1}$ If NOCs are less efficient than SOCs at producing marketable products from their vast reserves, we are likely to see lower oil production and higher oil prices than would be the case had the same resources been exploited by SOCs.

It may also be useful to understand why NOCs tend to be less efficiently managed than SOCs. As noted already, Hartley and Medlock (2008) argued that political pressure is likely to force NOCs to sell their products at below-market prices, but also to employ more workers than they really need. In effect, the firms are pressured into distributing resource rents to domestic consumers and workers, but in the process less value is obtained from the resources than would be the case were they exploited and sold at equivalent market prices. Once this dynamic is understood, governments or international organizations such as the World Bank may be in a better position to devise policies that can allow resource rents to be shared more efficiently.

In addition, a panel data set such as the one we investigate in this paper allows us to say something about how the relative efficiency of different firms has changed over time. We find that while oil and gas firms as a whole tended to become more efficient at producing revenue over the decade 2001-09, NOCs on average gained more than SOCs, generally moving closer to the revenue efficient frontier of the industry. We also find evidence that partial privatizations, along with mergers and acquisitions, are likely to result in increases efficiency. This is perhaps the very reason the privatizations, mergers or acquisitions occurred in the first place.

Finally, the comparison between particular NOCs and their NOC and SOC competitors may reveal something about how an inefficient NOC might be restructured to improve its efficiency. In particular, for any given inefficient firm the analysis reveals which efficient firms are most representative of the inefficient firm in terms of the operational variables. This, in turn, allows us to identify which firms may be suitable models to emulate. Some

\footnotetext{
${ }^{1}$ Looking further into the future, new technologies may enable more production from unconventional resources or introduce new oil substitutes that lessen the dominance of NOCs in the markets that oil products now serve.
} 
NOCs that are found to be as efficient as the major SOCs may also be suitable role models for governments wishing to improve the performance of their NOCs.

We use two methods to calculate revenue efficiency and changes in revenue efficiency: non-parametric data envelopment analysis (DEA) and parametric stochastic frontier analysis (SFA). DEA constructs the revenue efficient frontier as a piecewise-linear outermost limit of the set of observed input-output bundles in each year and then measures the distance of firms from that frontier. SFA involves estimating a revenue frontier from observed input-output bundles, and measures inefficiency as a one-sided random error component in the multivariate regression surface. The fact that we find similar results using very different techniques adds to the confidence that the results reflect genuine differences between firms rather than artifacts of the estimation methodologies. $^{2}$

\section{Related literature}

Despite the importance of NOCs in the world oil market, very few authors have examined the relative efficiencies of NOC's using formal econometric techniques such as DEA or SFA. Al-Obaidan and Scully (1991) used data for 44 firms in a single year, 1981, to construct a production frontier using both deterministic and stochastic methods. Specifically, they examined the ability of firms to use assets and employees to produce output, where output was defined as either revenue earned or the quantity of crude oil produced and processed. Relative to private firms, the authors found that NOCs are only $63 \%$ to $65 \%$ as efficient in generating revenue.

Although our results are generally consistent with those of Al-Obaidan and Scully, our study differs in many respects, particularly in the data used in the analysis. To begin, we use panel data in our analysis. We also include a broader set of oil companies than AlObaidan and Scully, who omit all OPEC nations arguing that the demonstrated efficiency

\footnotetext{
${ }^{2}$ It should be noted that the intent of using a dual approach is not to compare the two methodologies; rather, we are seeking to make more robust statements about the relative revenue efficiencies of the included firms.
} 
of those firms is "related more to the accident of geography than to the allocation of resources within the firm."

Our analysis can also be compared with two recent papers from the Electricity Policy Research Group at the University of Cambridge (Wolf (2008) and Wolf and Pollitt (2008)). Like Eller et al (2011), Wolf (2008) uses the Petroleum Intelligence Weekly annual publication "Ranking the World's 50 Top Oil Companies" (PIW Top 50) as his data source. ${ }^{3}$ He conducts a number of multivariate regression analyses with different dependent variables and two different types of estimators. In the latter regard, he considers a panel model with firm-specific intercept terms, and a total (or pooled ordinary least squares) estimator that ignores firm-specific heterogeneity in the data set. Wolf argues that the firm-specific intercept term in the fixed effects estimator captures "all (observed and unobserved) time-invariant variables" that affect the dependent variable. Thus, all firms that do not change ownership over the sample period are treated identically regardless of their extent of government or shareholder ownership. On the other hand, while the total estimator permits an estimation of the (cross-sectional) effect of ownership on the dependent variable of interest, it cannot control for any firm-specific unobserved variables.

The SFA analyses conducted in Eller et al (2011), and this paper, are also multivariate panel regression analyses, ${ }^{4}$ but with a special assumed structure on the error terms. In particular, in the simplest form of SFA, the error terms are assumed to have timeinvariant firm-specific components drawn from a distribution that is strictly nonnegative. There is also another component of the error, representing, for example, measurement error or omitted explanatory variables, that is assumed to have a symmetric distribution. ${ }^{5}$

\footnotetext{
${ }^{3}$ The PIW Top 50 is the precursor to the more comprehensive Energy Intelligence "Top 100: Ranking The World's Oil Companies," which is the source we used for the current paper.

${ }^{4} \mathrm{SFA}$ is a special type of random effects multivariate panel regression estimator. Wolf comments that he prefers the fixed effects panel estimator because the random effects estimator yields inconsistent results unless the firm-specific error terms are uncorrelated with the included measured variables. He rejects the latter hypothesis using a Hausman specification test.

${ }^{5}$ Greene (2005) proposed a modification of the basic SFA model to allow for fixed or random effects to measure firm heterogeneity apart from the one-sided random inefficiency term. In Eller et al (2011) and the
} 
By contrast, the standard random effects panel estimator, which implicitly assumes only symmetric error terms, ignores the differences in firm efficiency that will yield deviations from the most efficient firm. These differences will necessarily be one-sided.

Another difference between the analysis in Wolf (2008) and SFA is that theory imposes more structure on the estimated equation in SFA. In particular, as we discuss in more detail below, SFA directs one toward formulating a production function for the firm when choosing right hand side variables. By contrast, Wolf (2008) examines a range of dependent variables, none of which has a structural interpretation. This can make it difficult to specify the appropriate set of explanatory variables to include in the regression.

Of course, imposing more structure on the estimation could distort conclusions if the additional assumptions are inappropriate. That is a major motivation for also examining the relative efficiency of firms using non-parametric DEA. However, while DEA avoids making detailed assumptions about the underlying production function, it does not make allowance for measurement error or other sources of variation across firms that are unrelated to differences in inputs or relative efficiency.

Different from Wolf's analysis, but similar to that in Eller et al (2011), the methods we employ require a balanced panel. In other words, we can only include firms in the data set if they have observations for all variables included in the analysis for all the years included in the data set. This ultimately reduces the number of years and firms in our data set. $^{6}$

The paper by Wolf and Pollitt (2008) also is relevant to our current investigation. They focus on 60 share-issue privatizations by 28 former NOCs (from 20 different countries)

\footnotetext{
analysis conducted below we estimate a parametric model where the firm-specific error component contains two terms (the time variable and government ownership share) that can be regarded as "inefficiency" effects and one term (a vertical integration measure) that is more appropriately regarded as a control for firm heterogeneity.

${ }^{6}$ For example, including 2000 in addition to 2001-09 would have eliminated an additional 10 firms from our data including some important NOCs. By contrast, Wolf examines data from 1987-2006, but he has missing data for at least some of the variables for many firms in many years.
} 
from 1977 to 2004. Many of these were follow-on offerings as government ownership shares were reduced in several steps. The NOCs included in their sample are predominantly from the more developed world (17 of the 28 are from OECD countries and none are from OPEC). The authors collected firm performance data ${ }^{7}$ for seven-year periods surrounding each offering. ${ }^{8}$ They then compared mean performance three years prior to the asset sale to mean performance three years after the asset sale. They generally found that privatization is associated with higher profitability, improved operating efficiency, greater output and lower employment.

The authors also estimated a fixed effects panel data model allowing the intercept and the coefficient on "year" (a discrete variable ranging from 1-7 beginning 3 years prior to the privatization and ending 3 years after the asset sale) to differ before and after the privatization. ${ }^{9}$ They found that initial share-issue privatizations improved average performance by all measures, but the effect was statistically significant at the $10 \%$ level only for increased return on sales or assets and reduced employment per unit of assets. The trend in performance was favorable for all metrics, and statistically significantly so at the $1 \%$ level for increased return on sales or assets, output per employee, output, and reduced employment per unit of assets. On the other hand, the trend after privatization was less favorable than the trend prior to privatization for seven out of ten indicators (although statistically significant only for returns on sales or assets). Wolf and Pollitt conclude that performance generally improves as a result of privatization but the improvements begin in anticipation of the subsequent share sale and, if anything, tend to slow down after the shares are sold.

\footnotetext{
${ }^{7}$ The performance metrics included returns on sales, assets and equity; output, revenue and net profit per employee; finding and development, and production, costs per barrel of oil equivalent; reserve replacement ratio; capital expenditure; financial leverage and dividend payments.

${ }^{8}$ In many cases, this produced a continuous sample from three years prior to the first offering to three years after the final offering.

${ }^{9}$ The intercept term thus measures the change in average performance as a result of privatization while the year coefficients measure changes in performance trends. Unlike the simple comparison of before and after means, the panel regression models also allowed them to control for other firm-specific influences and changes in the real oil price.
} 
The authors also examined the effects of follow-on share offerings subsequent to the initial privatization. The results were much less conclusive than for initial privatizations. The only strong result was that continued reductions in government ownership were associated with continued reductions in employment $-\mathrm{a}$ finding that is consistent with some of the results we report below.

Victor (2007) analyzed data from the 1999-2006 editions of Energy Intelligence "Top 100: Ranking The World's Oil Companies." Like Wolf (2008) and Wolf and Pollitt (2008), she examines a range of performance indicators including revenue per employee, return on assets, liquids and natural gas production relative to liquids and natural gas reserves (respectively), and revenue relative to production. However, these analyses are each one dimensional, raising the possibility of omitted variable bias in the estimated coefficients. They also are all conducted as simple regressions without any allowance for the possibility that constraints on the maximum level of efficiency that can be attained at any one time are likely to lead to asymmetric error terms.

\section{Overview of methods}

By definition, the observed input-output bundle of an efficient firm is on the production frontier, whereas an inefficient firm will be inside the production frontier. In our application, the output variable for firm $i$ in year $t, y_{i t}$, is revenue in millions of current $\$$ US. The inputs, $x_{i k t}$ where $k=1 \ldots K$, are oil (millions of barrels) reserves, natural gas (billions of cubic feet) reserves, distillation capacity (thousands of barrels per day), employees (head count at the end of the year), and oil (current \$US per barrel) and natural gas (current \$US per MMBTU) prices. These choices were motivated by the theoretical analysis of NOC behavior in Hartley and Medlock (2008). Specifically, Hartley and Medlock (2008) assumed that current output $Q$ of an oil-producing firm is given by

$$
Q=F(L) \times R s v \times G(E)
$$


where $L$ is labor input, $R s v$ is proved reserves, and $G(E)$ represents geological limitations on field productivity that depend on the level of cumulative past exploitation, $E .^{10}$ In its downstream operations, the firm uses labor and capital (especially refining capacity) along with crude and wellhead natural gas to produce marketable products $q$, such that

$$
q=H(K, L, Q)
$$

Revenue will then be given by

$$
p(1-s)^{\circ} q
$$

for a vector of product prices $p$ and corresponding percentage subsidies $s$ on each marketable product. While the relative prices of the different products will vary, they will be cointegrated with crude oil prices, so we simply used the latter herein as a proxy for all the relevant oil product prices.

As already noted, we use both DEA and SFA to determine the technological frontier and the distance of firms from that frontier. DEA uses linear programming techniques to construct a non-parametric piecewise-linear convex hull of observed input-output bundles. The DEA efficiency scores can then be used to measure changes in efficiency from one year to the next. Specifically, we calculate the Malmquist indices of total factor productivity changes for each firm in the sample. SFA involves estimating a parametric production frontier from observed input-output bundles using panel data estimation techniques adapted for this problem.

As noted above, an advantage of DEA relative to SFA is that it requires no assumptions regarding the functional form of the production technology, and it is not subject to the potential problems of assuming an inappropriate distribution of the error term. However,

\footnotetext{
${ }^{10}$ The maximum annual output $Q$ obtainable from a given level of proved reserves is bounded by an amount that will depend on geological factors such as reservoir pressure and porosity. Over time, enhanced recovery techniques may be required to keep older reservoirs producing. In addition, reservoirs that are easier to exploit are likely to be mined first. We do not have any data on the geological characteristics or the average age of the reservoirs exploited by the different firms. These factors, therefore, are likely to be significant components of the error terms in the models that we subsequently estimate using SFA.
} 
since DEA does not account for statistical noise, estimates of efficiency will be biased when stochastic elements are a prominent feature of the true production process or the variables used in the analysis are measured with error.

SFA, by contrast, provides a statistical measure of how well the proposed model explains the data. A potential weakness, however, is that one has to specify a structural relationship between inputs and outputs and assume a model for the stochastic terms. In particular, while the assumption that the $y_{i t}$ is revenue and the $x_{i k t}$ are productive inputs places restrictions on reasonable functional forms for the relationship between $y_{i}$ and the $x_{i k}$ variables, the dependence of the inefficiency terms $u_{i}$ on time or other covariates is not constrained by theory. If these auxiliary assumptions are inaccurate, the resulting inferences about the underlying model may be compromised.

Both DEA and SFA have been used extensively to analyze productive efficiency. Comparison of methods is available in Gong and Sickles (1992), Banker (1993), Cooper and Tone (1997), and Ruggiero (2007), to name a few. Our intention is not to examine the relative merits of different methods for measuring efficiency. Rather, we explore several approaches in attempt to ensure our conclusions do not simply reflect limitations of any single mode of analysis. ${ }^{11}$

\section{The data set}

As in Eller et al (2011), Victor (2007) and Wolf (2008), the primary data source was the Energy Intelligence annual publication "Ranking the World's Oil Companies". However, we also consulted company annual reports to check and revise some of the published data and to provide missing data.

\footnotetext{
${ }^{11}$ Recent econometric literature has attempted to bridge the gap between the DEA and SFA by introducing statistical noise into DEA or by using a non-parametric formulation for inefficiency in SFA. Grosskopf (1996) provides an early survey of literature on statistical inference in DEA models. Desai et al. (2005) modified the constraints in DEA so they only needed to hold probabilistically. Tsionas (2003) discusses using DEA estimates of efficiency as priors for the one-sided errors in an SFA model, which then are derived as posterior estimates in a Monte Carlo Bayesian analysis.
} 
We began with almost 150 firms, but, as noted above, the methods that we use require a balanced panel so a firm missing just one variable in one year had to be dropped from the sample. This constrained both the number of years and the number of firms we could include in the data set. In addition, to obtain measures for all variables for each firm in the sample, for firms that merged we combined the inputs and revenues of merger partners in years prior to the merger. This further reduced the number of separate firms in the sample. To keep track of the "synthetic" firms so formed, we defined an indicator variable (Premerge) that was set to 1 in the years before the firms merged and to zero in years following the merger. Ultimately, we were left with 61 firms covering the period 2001-2009, which compares with a sample of 78 firms over three years (2002 to 2004) in Eller et al (2011). ${ }^{12}$

Table 1 lists the averages of key variables for each company in the sample. As already noted, revenue is the output variable, while oil and natural gas reserves, refining capacity and employees are production inputs.

We also used data on oil and natural gas prices from the US Energy Information Administration (EIA) and the International Energy Agency (IEA). We used the average annual US import oil price for North American firms, the average annual OPEC oil price for OPEC members, and the average non-OPEC oil price for other firms in the sample. For natural gas prices, we used the average annual prices at the Henry Hub for North American firms, average annual Japanese LNG import prices for firms in Asia, the Pacific and the Middle East, EU pipeline import prices for firms predominantly selling in Europe, and EU LNG import prices for LNG exporting firms in the Atlantic Basin. ${ }^{13}$

\footnotetext{
${ }^{12}$ We subsequently dropped an additional firm, Nippon Oil, after the analysis revealed that its very heavy concentration in downstream product markets made it an extreme outlier. Specifically, Nippon Oil product sales were on average almost 20 times its liquids production, compared with a mean across all firms of slightly less than 1.5 and mean for the next highest firm of slightly more than 8.5. Including Nippon Oil in the analysis substantially altered the effect of this measure of vertical integration, although most of the remaining coefficients were not much affected by its inclusion.

${ }^{13}$ We note, however, that the different oil and natural gas prices are very highly correlated with each other. Results were not materially affected by using just one "representative" price series for each commodity.
} 
Table 1: Means of key variables

\begin{tabular}{|c|c|c|c|c|c|c|c|c|c|}
\hline Firm & $\begin{array}{l}\text { Headquarter } \\
\text { Country }\end{array}$ & $\begin{array}{l}\text { Government } \\
\text { ownership } \\
\text { share }\end{array}$ & $\begin{array}{l}\text { Revenue } \\
\text { (\$ million) }\end{array}$ & $\begin{array}{l}\text { Oil } \\
\text { reserves } \\
\text { (million } \\
\text { barrels) }\end{array}$ & $\begin{array}{l}\text { Nat. gas } \\
\text { reserves } \\
(\text { billion } \\
\left.\mathbf{f t}^{3}\right)\end{array}$ & $\begin{array}{l}\text { Refining } \\
\text { Capacity } \\
\text { (thousands } \\
\text { barrels/day) }\end{array}$ & Employees & $\begin{array}{l}\text { Revenue } \\
\text { per } \\
\text { employee }\end{array}$ & $\begin{array}{l}\text { Vertical } \\
\text { integration } \\
\text { (products/ } \\
\text { oil prod) }\end{array}$ \\
\hline Adnoc & UAE & 1 & 27260.3 & 54590.6 & 138424.0 & 633.1 & 85000 & 0.321 & 0.230 \\
\hline Anadarko & US & 0 & 10208.1 & 1366.2 & 9650.2 & 0 & 5812 & 2.000 & 0 \\
\hline Apache & US & 0 & 6865.9 & 925.7 & 6323.4 & 0 & 2826 & 2.295 & 0 \\
\hline $\mathrm{BG}$ & UK & 0 & 11412.4 & 591.1 & 9164.3 & 0 & 5075 & 2.166 & 0 \\
\hline BHPBilliton & Australia & 0 & 32934.9 & 586.7 & 4917.8 & 0 & 36287 & 0.882 & 0 \\
\hline $\mathrm{BP}$ & UK & 0 & 245861.0 & 9817.8 & 46815.3 & 2963.9 & 100354 & 2.511 & 2.662 \\
\hline $\mathrm{CNOOC}$ & China & 0.68 & 10896.9 & 1483.7 & 5009.8 & 0 & 2735 & 3.551 & 0.047 \\
\hline CNPC & China & 0.93 & 90987.8 & 15887.0 & 62646.4 & 2391.4 & 450057 & 0.194 & 0.687 \\
\hline CNR & Canada & 0 & 7565.9 & 1943.2 & 3024.9 & 0 & 2661 & 2.845 & 0 \\
\hline Chesapeake & US & 0 & 5028.3 & 87.2 & 6778.6 & 0 & 3792 & 1.379 & 0 \\
\hline Chevron & US & 0 & 167549.0 & 8320.0 & 24730.4 & 2197.2 & 66478 & 2.566 & 1.967 \\
\hline ConocoPhillips & US & 0 & 132733.0 & 6070.6 & 24388.3 & 2690.7 & 41245 & 3.663 & 1.990 \\
\hline Devon & US & 0 & 8896.7 & 903.8 & 8010.9 & 0 & 4418 & 1.981 & 0 \\
\hline ENI & Italy & 0.30 & 92411.8 & 3694.2 & 18261.1 & 719.3 & 74978 & 1.227 & 1.015 \\
\hline EOG & US & 0 & 3233.1 & 143.7 & 5793.0 & 0 & 1476 & 2.074 & 0 \\
\hline Ecopetrol & Colombia & 0.96 & 8126.7 & 1232.7 & 2928.2 & 320.4 & 6516 & 1.271 & 0.787 \\
\hline EnCana & Canada & 0 & 13724.9 & 765.1 & 10280.7 & 50.2 & 4394 & 2.933 & 0.376 \\
\hline ExxonMobil & US & 0 & 295090.0 & 11851.0 & 62626.4 & 6300.9 & 86356 & 3.496 & 2.948 \\
\hline Gazprom & Russia & 0.48 & 66477.9 & 13370.7 & 855000.0 & 631.3 & 386580 & 0.170 & 0.594 \\
\hline Hess & US & 0 & 23420.9 & 819.4 & 2580.4 & 255.3 & 11882 & 1.938 & 1.613 \\
\hline Husky & Canada & 0 & 10138.9 & 513.6 & 1749.0 & 106.8 & 3525 & 2.686 & 0.641 \\
\hline $\mathrm{KPC}$ & Kuwait & 1 & 47983.8 & 98771.7 & 58474.1 & 1077.6 & 19426 & 2.686 & 0.446 \\
\hline Lukoil & Russia & 0.02 & 47998.7 & 13974.4 & 21893.3 & 1091.6 & 147056 & 0.321 & 0.810 \\
\hline Maersk & Denmark & 0 & 6005.2 & 728.6 & 1572.2 & 0 & 3500 & 1.716 & 0 \\
\hline Marathon & US & 0 & 48842.1 & 792.1 & 3230.3 & 991.2 & 27395 & 1.765 & 6.588 \\
\hline Mol & Hungary & 0.11 & 11585.6 & 119.7 & 943.1 & 303.8 & 17279 & 0.692 & 6.307 \\
\hline MurphyOil & US & 0 & 12490.6 & 330.9 & 519.7 & 211.8 & 6237 & 1.824 & 3.783 \\
\hline NIOC & Iran & 1 & 43765.0 & 127229.0 & 950214.0 & 1517.9 & 114956 & 0.381 & 0.426 \\
\hline
\end{tabular}




\begin{tabular}{|c|c|c|c|c|c|c|c|c|c|}
\hline Nexen & Canada & 0 & 4096.4 & 682.0 & 597.9 & 0 & 3371 & 1.165 & 0 \\
\hline Nippon & Japan & 0 & 50212.7 & 110.9 & 1334.0 & 1252.6 & 13729 & 3.684 & 19.751 \\
\hline Noble & US & 0 & 2171.0 & 258.1 & 2528.7 & 0 & 1043 & 2.064 & 0 \\
\hline OMV & Austria & 0.36 & 18972.7 & 555.4 & 2359.3 & 458.2 & 30627 & 0.839 & 3.217 \\
\hline ONGC & India & 0.77 & 11553.9 & 3768.9 & 15692.6 & 155.9 & 35893 & 0.332 & 0.329 \\
\hline Occidental & US & 0 & 14626.4 & 2254.0 & 3839.6 & 0 & 8863 & 1.624 & 0 \\
\hline PDO & Oman & 0.6 & 9793.3 & 3194.4 & 18958.1 & 65.0 & 4446 & 2.167 & 0.107 \\
\hline PDV & Venezuela & 1 & 76195.7 & 83753.9 & 158427.0 & 3073.9 & 53391 & 1.506 & 0.968 \\
\hline PTT & Thailand & 0.79 & 28706.1 & 144.1 & 4795.1 & 315.9 & 7530 & 3.463 & 8.558 \\
\hline Pemex & Mexico & 1 & 82189.8 & 14341.1 & 14126.8 & 1705.3 & 139787 & 0.585 & 0.467 \\
\hline Pertamina & Indonesia & 1 & 29054.2 & 2765.0 & 46753.2 & 1035.3 & 28578 & 1.037 & 5.168 \\
\hline Petrobras & Brazil & 0.42 & 63511.6 & 9410.8 & 11219.8 & 2105.7 & 57381 & 1.038 & 1.434 \\
\hline Petroecuador & Ecuador & 0.89 & 4609.0 & 3063.7 & 611.0 & 175.9 & 4011 & 1.150 & 0.715 \\
\hline Petronas & Malaysia & 1 & 44752.2 & 7036.2 & 104663.0 & 386.3 & 30874 & 1.383 & 0.856 \\
\hline Pioneer & US & 0 & 1475.7 & 422.1 & 2756.4 & 0 & 1467 & 1.000 & 0 \\
\hline Plains & US & 0 & 1630.0 & 367.0 & 1156.3 & 0 & 816 & 1.959 & 0 \\
\hline QP & Qatar & 1 & 21946.7 & 12703.1 & 603147.0 & 177.8 & 6976 & 3.140 & 0.148 \\
\hline Repsol YPF & Spain & 0 & 59294.7 & 1415.7 & 12686.6 & 1226.8 & 35208 & 1.665 & 2.412 \\
\hline Rosneft & Russia & 0.83 & 26398.1 & 11091.3 & 51326.7 & 493.8 & 88611 & 0.253 & 0.645 \\
\hline Santos & Australia & 0 & 1741.8 & 147.4 & 2522.3 & 0 & 1743 & 0.986 & 0 \\
\hline SaudiAramco & SaudiArabia & 1 & 175363.0 & 263055.0 & 246052.0 & 2309.7 & 53475 & 3.282 & 0.301 \\
\hline Shell & Netherlands & 0 & 277173.0 & 6424.2 & 41434.7 & 3993.0 & 107828 & 2.591 & 3.315 \\
\hline Sinopec & China & 0.68 & 113067.0 & 3147.9 & 4286.1 & 3316.0 & 387585 & 0.309 & 2.594 \\
\hline Sonangol & Angola & 1 & 7810.3 & 2978.3 & 1158.4 & 34.1 & 5611 & 1.409 & 0.082 \\
\hline Sonatrach & Algeria & 1 & 43917.8 & 11003.6 & 151148.0 & 471.1 & 45922 & 0.996 & 0.429 \\
\hline Statoil Hydro & Norway & 0.62 & 77736.0 & 2636.8 & 20784.3 & 340.3 & 49439 & 1.852 & 0.497 \\
\hline Suncor & Canada & 0.02 & 24282.9 & 2075.1 & 2456.7 & 407.1 & 10274 & 2.228 & 1.159 \\
\hline Surgutneftegas & Russia & 0 & 15712.8 & 7289.6 & 13584.3 & 358.6 & 95346 & 0.160 & 0.287 \\
\hline TNK-BP & Russia & 0 & 25509.9 & 5524.2 & 6002.9 & 415.7 & 83285 & 0.380 & 0.358 \\
\hline Talisman & Canada & 0 & 5361.1 & 589.8 & 3970.7 & 0 & 2178 & 2.389 & 0 \\
\hline Total & France & 0 & 148744.0 & 6527.0 & 24123.4 & 2648.0 & 107115 & 1.435 & 2.221 \\
\hline Wintershall & Germany & 0 & 10819.2 & 484.6 & 3329.8 & 9.4 & 1736 & 5.955 & 0.116 \\
\hline Woodside & Australia & 0 & 2307.7 & 224.3 & 3817.0 & 0 & 2698 & 0.824 & 0 \\
\hline XTO & US & 0 & 3906.1 & 222.1 & 6694.6 & 0 & 1824 & 1.850 & 0 \\
\hline
\end{tabular}




\section{Analysis}

\subsection{Data envelopment analysis}

We used the program DEAP 2.1 written by Tim Coelli to calculate the DEA measures. We assumed that the technology displays constant returns to scale. While an assumption of variable returns to scale allows for wider variations in technologies across firms allowing more firms to be measured as efficient, the assumption of variable returns also renders firms more difficult to compare.

DEA solves the following linear programming problem. Suppose we have $N$ firms each using $K$ inputs to produce a single output. ${ }^{14}$ Define $X$ as the $K \times N$ matrix of inputs, $Y$ as the $1 \times N$ vector of outputs from all the firms, and let $x_{i}$ and $y_{i}$ denote the inputs and output, respectively, of firm $i$. The constant returns to scale output-oriented distance function $D\left(y_{i}, x_{i}\right)$ of firm $i$ is then calculated by solving:

$$
\left[D\left(y_{i}, x_{i}\right)\right]^{-1} \equiv \max _{\theta, \lambda} \theta
$$

subject to

$$
-\theta y_{i}+Y \lambda \geq 0, x_{i}-X \lambda \geq 0 \text { and } \lambda \geq 0
$$

where $0<D\left(y_{i}, x_{i}\right) \leq 1$ is the technical efficiency score and $\lambda$ is an $N \times 1$ vector of constants. This programming problem is solved for each firm $i$ and thus a total of $N$ times in each year.

It is useful for the subsequent discussion to briefly explain the idea behind this linear programming problem. Imagine forming a weighted average of existing firms, referred to below as a "composite firm," to be compared with firm $i$ with $\lambda_{j}$ being the weight of firm $j$ in this composite. ${ }^{15}$ The composite firm uses inputs $X \lambda$ at most equal to the inputs $x_{i}$ used by firm $i$ while producing output $Y \lambda$ at a minimum equal the output $y_{i}$ of firm $i$. A

\footnotetext{
${ }^{14}$ While the concept is defined for multiple outputs as well as multiple inputs, we will only be considering a uni-dimensional output, namely revenue.

${ }^{15}$ If we assume the technology has constant returns to scale then the composite firm can be compared with a re-scaled version of firm $i$ and the $\lambda$ weights need not sum to one. If we cannot assume constant returns to scale, the composite firm needs to match a full-sized copy of firm $i$ and the weights $\lambda$ need to sum to 1 .
} 
firm $i$ that is efficient would have $\theta=1$ and all components of $\lambda$ except for the $i$-th one equal to zero while $\lambda_{i}=1$. If a value $\theta>1$ can be found for firm $i$, however, then that firm is not efficient and $\theta$ measures how much firm $i$ has to increase its output to become efficient. In addition, if the composite firm would use strictly less of some inputs than does firm $i$ (that is, $x_{i}-X \lambda \geq 0$ is non-binding for some inputs), firm $i$ also is inefficient in the sense that it could produce the same output using less of these particular inputs.

Figure 1 graphs the DEA efficiency scores for each firm and year in our sample. The firms have been grouped into three broad categories - national oil companies (NOCs), shareholder-owned oil companies (SOCs) and part national-owned oil companies (pNOCs). The latter group includes two sub-groups - four firms (PTT, Rosneft, Ecopetrol and CNPC) that were fully national-owned for some years and four (Lukoil, Suncor, Mol and Petroecuador) that were fully shareholder-owned for some years. Within each group or sub-group, firms have been ordered according to their average DEA score over the full nine years.

Looking at the movements from one year to the next, it is clear that the efficiency scores for most of the firms increased over the nine-year sample period. There are, however, some notable exceptions. Among private firms, Occidental, Chesapeake, BG, EOG, CNR, Devon, Talisman, Noble and Plains all have lower relative efficiency scores in 2009 that in earlier years (this is around one-third of the SOCs).

Among the NOCs, only PDV from Venezuela has a lower score in 2009 than in any earlier year. In fact, after beginning at slightly above 0.5 in 2001, PDV's score rose to a maximum of slightly above 0.6 in 2004 before falling back to below 0.3 in 2009 . The partially privatized firm, PDO from Oman also displays a similar rise and fall pattern, starting at around 0.3 in 2001, rising to a maximum efficiency score of almost 0.8 in 2007 and then falling back to around 0.44 by 2009 . 


\section{Figure 1: DEA efficiency scores}

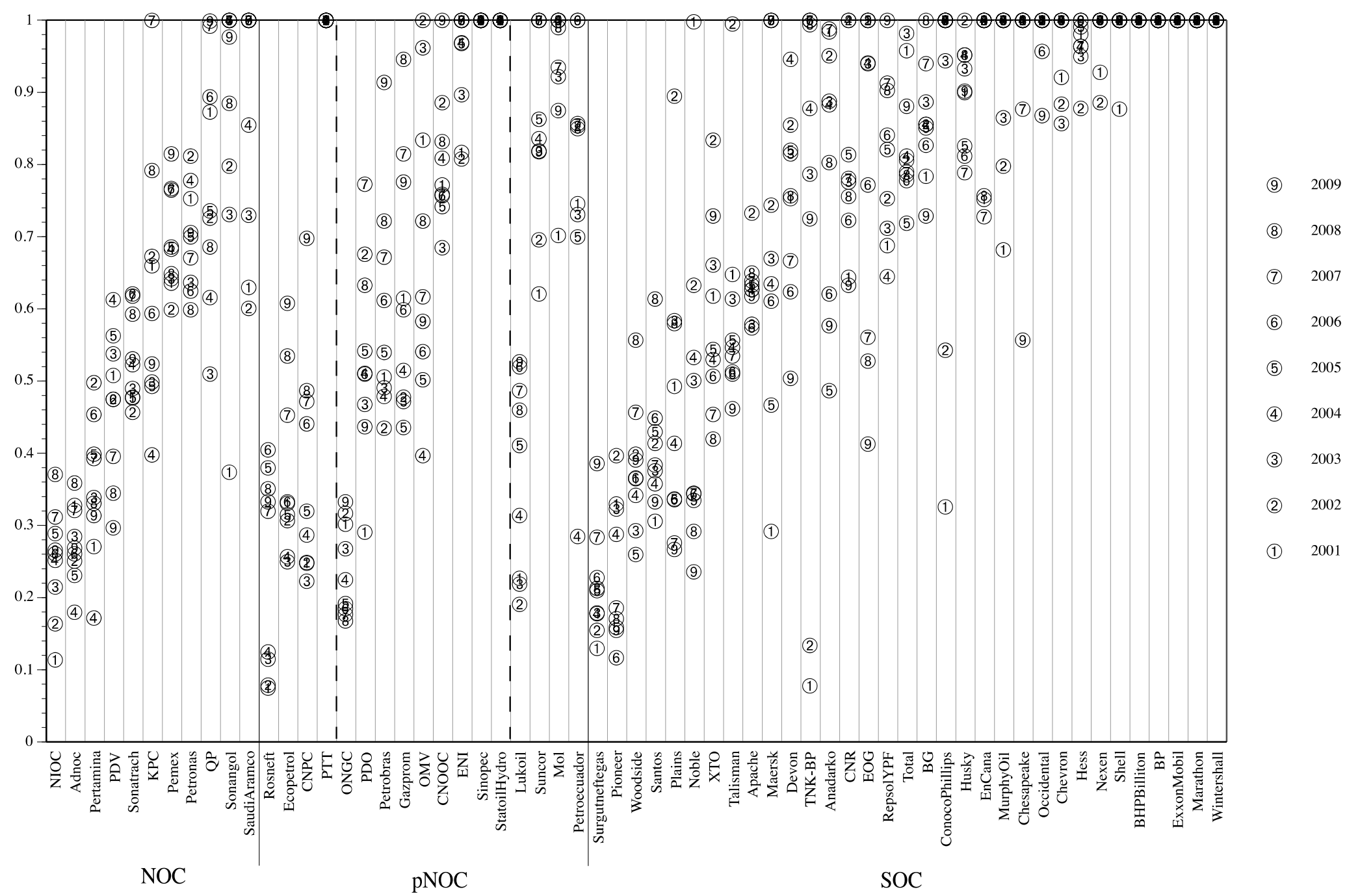


A particularly interesting case is TNK-BP. It begins (as a Russian only firm) with a DEA score of 0.078 in 2001, second only to fellow Russian firm Rosneft in terms of its relative inefficiency. Following the formation of TNK-BP in 2003, however, the DEA score jumps to 0.787 . The firm then attains the frontier in 2005 and remains there until 2007. After the resolution of a dispute between the joint venture partners in late 2008, however, which was widely regarded to have increased the influence of the Russian side in the joint venture, its relative efficiency declines again as its DEA score falls back to 0.725 by 2009.

Figure 1 also reveals some interesting observations on the partially privatized firms. The most efficient of these firms, Statoil-Hydro, Sinopec and PTT, look like the most efficient SOCs with DEA scores of 1 that place them on the frontier in every year. ENI improves more or less monotonically over time to end up on the frontier by 2006 . While CNOOC also ends up on the frontier in 2009, its relative progress in earlier years is more erratic. Petrobras makes substantial gains in relative efficiency over the decade, ending up at 0.914 in 2009.

The two standout NOCs are Saudi Aramco and Sonangol. In particular, Saudi Aramco is on the frontier from 2005. Sonangol is also on the frontier from 2004 through 2007 but falls back to a DEA score of 0.885 in 2008, rising again to 0.977 in 2009. Qatar Petroleum almost attains the frontier in 2009 with a score of 0.999 , is slightly further below in 2007 with a score of 0.992, and has a higher efficiency score than Saudi Aramco in 2001 and 2002. Kuwait Petroleum Corporation attains the frontier in just one year (2007), and almost scores 0.8 in 2008, but otherwise has efficiency scores in the 0.4 to 0.67 range.

Table 2 summarizes the average DEA efficiency scores for each group of firms for each of the years 2001-2009. In this table, pNOCs have been placed in the NOC group in any years they were fully government owned and in the SOC group in any year they were fully privatized. The remaining firms in the pNOC category in each year therefore had government ownership shares strictly between 0 and 1 . We have also included the average government ownership share in these firms for each year of the sample as well as the average across all years. 
Table 2: Average DEA efficiency scores by ownership category

\begin{tabular}{ccccc}
\hline Year & SOC & NOC & pNOC & $\begin{array}{c}\text { pNOC mean } \\
\text { government share }\end{array}$ \\
\hline 2001 & 0.729 & 0.518 & 0.610 & 0.494 \\
2002 & 0.804 & 0.553 & 0.672 & 0.492 \\
2003 & 0.776 & 0.514 & 0.672 & 0.534 \\
2004 & 0.785 & 0.544 & 0.610 & 0.558 \\
2005 & 0.765 & 0.614 & 0.602 & 0.582 \\
2006 & 0.764 & 0.663 & 0.645 & 0.603 \\
2007 & 0.777 & 0.677 & 0.716 & 0.585 \\
2008 & 0.797 & 0.611 & 0.742 & 0.585 \\
2009 & 0.746 & 0.616 & 0.749 & 0.589 \\
\hline Average & $\mathbf{0 . 7 7 1}$ & $\mathbf{0 . 5 8 6}$ & $\mathbf{0 . 6 6 8}$ & $\mathbf{0 . 5 5 7}$ \\
\hline
\end{tabular}

In most years, the average DEA efficiency score for pNOCs lies between that of the NOCs and the SOCs. The exceptions are 2005 and 2006, when the NOCs had a higher average score than the pNOCs and 2009 when the pNOCs had a slightly higher average score than the SOCs. In the latter case, the average score for SOCs in 2009 was lower than any year since 2001, while that of the pNOCs was higher than in any other year. If one looks at the trends in the averages over the nine years, one cannot reject the hypothesis that the SOC average oscillates around a constant value of 0.769 , while the averages for the NOCs rise at about 0.017 per year and of the pNOCs at about 0.015 per year. In addition, the NOC and pNOC averages oscillate more about their trend from year to year. Part of the explanation for the fact that the NOCs and pNOCs gain on the SOCs is that more of the SOCs are on the frontier year after year and hence their DEA efficiency scores are always 1 .

We can obtain more systematic evidence on the relationship between government ownership and the DEA efficiency score by regressing the annual scores of each firm against the government ownership share in the same year. In doing so, however, we need to account for the fact that the DEA efficiency score is, by definition, bounded above by $1 .{ }^{16} \mathrm{We}$ therefore estimate a Tobit regression model, which takes the truncation into account by assuming that an observation of 1 for the dependent variable merely tells us that the error term is bounded below by an observed value. In addition, the panel nature

\footnotetext{
${ }^{16}$ The DEA score is truncated at 1 for 167 out of 549 observations.
} 
of the data needs to be taken into account. Specifically, we expect there to be firmspecific effects, such as the geological or market conditions that a firm faces, that are unmeasured and many of which are likely to be constant or nearly constant over the sample period. Thus, the panel Tobit model assumes that the dependent variable (the DEA score in our case) satisfies

$$
y_{i t}=x_{i t} \beta+v_{i}+\varepsilon_{i t}
$$

for $i=1,2, \ldots n$ panels and $t=1,2, \ldots, T$ periods with $v_{i}+\varepsilon_{i t}=y_{i t}-x_{i t} \beta$ observed if $y_{i t}<1$ and $v_{i}+\varepsilon_{i t} \geq 1-x_{i t} \beta$ otherwise. The random firm-specific effects $v_{i}$ are assumed to be independently identically distributed (i.i.d.), independent of the i.i.d. error terms $\varepsilon_{i t}$ and independent of the regressors $x_{i t}$.

We examined several models. In the basic specification, we allowed both the intercept and time trend to depend on the actual government ownership share (GovShare). We also allowed the intercept and trend to take just three different values, one when GovShare $=1$ (NOCs), one when GovShare $=0$ (SOCs) and a third when GovShare is strictly between 0 and 1 (pNOCs). The best model lumped NOCs and pNOCs together with a common trend in DEA efficiency score and did not yield a trend in the DEA score for SOCs that was significantly different from zero (here and in all subsequent regression equations, standard errors are reported in parentheses below the estimated coefficients): ${ }^{17}$

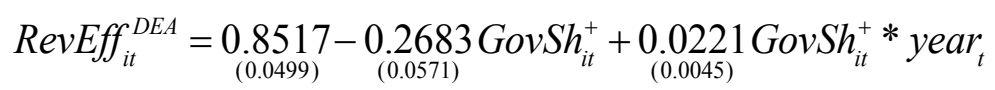

\footnotetext{
${ }^{17}$ In a model that includes the amount of government ownership and its interaction with year along with categorical variables for GovShare $=1$ (NOC) and $0<$ GovShare $<1$ (pNOC) and their interactions with year, the coefficients on GovShare, year and GovShare *year are individually not statistically significantly different from zero and a test for the joint significance has a $p$-value of 0.7904 . Furthermore, after dropping these variables, a test for equality of the coefficients on NOC and pNOC had a $p$-value of 0.4466 , while a test for equality of the coefficients on the interactions NOC*year and pNOC*year had a $p$-value of 0.8963. Finally, the log likelihood for the estimated model (6) is -28.6599 compared to -31.9477 for a model that includes GovShare and GovShare*year in place of the regressors in (6).
} 
where $\mathrm{GovSh}_{i t}^{+}$(which equals NOC + pNOC) is an indicator variable taking the value 1 if GovShare $>0$ and zero otherwise and year takes the values 1-9 for 2001-2009. Each of the coefficients in (6) is significantly different from zero at a better than 0.001 level. The implication of equation (6) is that any amount of government ownership share decreases the average DEA score by more than $30 \%$ in 2001 (0.5833 compared to 0.8517 ).

However, such firms also gain an average of 0.022 per year in DEA score so that by 2009 , they have an average DEA score that is only about $8 \%$ below the average score for shareholder owned firms. It is also interesting to note the estimated values of $\sigma_{v}=0.3307$ (standard error 0.0350 ) and of $\sigma_{\varepsilon}=0.1648$ (standard error 0.0065 ), indicating that more than $80 \%$ of the estimated variance is due to the firm-specific error components.

Systematic factors apart from the government ownership share could also be expected to affect the efficiency score. In particular, we noted when discussing the data that we constructed a variable Premerge that took the value 1 for firms that subsequently merged and was set to zero for years following a merger or for firms that were not involved in a merger during the sample period. If mergers increase efficiency we would expect Premerge to negatively affect the DEA score.

As we also noted above, the theoretical model of NOC behavior considered by Hartley and Medlock (2008) emphasized that political pressure is likely to force a NOC to sell products to domestic consumers at subsidized prices. We thus would expect measured inefficiencies to be systematically related to the presence of retail fuel subsidies. We tested for this possibility by including a variable RetSubs. This took the value zero for countries with average retail prices of gasoline and diesel above those of the US (including the US itself) while for countries where the average retail prices were lower than in the US, the extent of subsidy was measured by the percent deviation below the US average in the same year. ${ }^{18}$

\footnotetext{
${ }^{18}$ Retail gasoline and diesel fuel prices were obtained from the Metschies surveys of international fuel prices. Since the Metschies data is biennial, we used the average of the two percentage subsidies from the two adjacent years to proxy the percentage subsidy in the missing years. In Eller et al (2011), we used the
} 
Finally, while we included refinery capacity among the inputs, firms with large retail operations would also have substantial capital invested in those operations that are not measured among the inputs. Such firms might then artificially appear more efficient. We therefore also defined a variable VertInt equal to the ratio of product sales (in thousands of barrels per day) to annual liquids production (also measured in thousands of barrels per day) to measure the extent to which the firm is involved in downstream markets.

Once again, the best model grouped NOCs and pNOCs together with a common trend in DEA efficiency score and did not yield a significant trend in the DEA score for SOCs: ${ }^{19}$

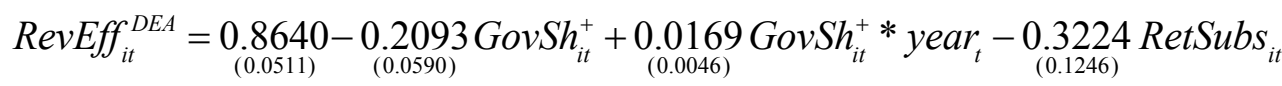

$$
\begin{aligned}
& -\underset{(0.0455)}{0.1351 \text { Premerge }_{i t}}+\underset{(0.0112)}{0.0157 \text { VertInt }_{i t}}
\end{aligned}
$$

The coefficients on $\mathrm{GovSh}_{i t}^{+}$and $\mathrm{GovSh}_{i t}^{+}$* year ${ }_{t}$ in (7) are significantly different from zero at a better than $1 \%$ level, and have similar magnitudes to the corresponding coefficients in (6), suggesting that the strong negative effects of government ownership on efficiency cannot be explained by the other factors on the right-hand side of (7). The estimated values imply that any non-zero government ownership share decreases the average DEA score by more than $24 \%$ below the average score of 0.8640 for SOCs in 2001 (holding other variables fixed ${ }^{20}$ ), but by 2009 such firms have an average DEA score that is only about $6.6 \%$ below the average for corresponding SOCs.

\footnotetext{
same data but coded the subsidy variable $0-1$ to indicate whether the country had an average gasoline and diesel price below the corresponding average of the two prices in the US.

${ }^{19}$ Estimating a model that includes GovSharei, year and their interactions along with NOC and pNOC and their interactions with year, the coefficients on GovShare, year and GovShare*year are individually and jointly insignificantly different from zero ( $p$-value 0.8845 ). Furthermore, after dropping these variables, a test for equality of the coefficients on NOC and pNOC had a $p$-value of 0.8487 , while a test for equality of the coefficients on the interactions NOC*year and pNOC*year had a $p$-value of 0.6031 . Finally, the $\log$ likelihood for the estimated model (7) is -18.4300 compared to -21.0310 for a model that includes GovShare and GovShare*year as regressors in place of the first two regressors in (7).

${ }^{20}$ As we note below, however, the remaining variables in the regression are unlikely to be the same for SOCs relative to NOCs and pNOCs.
} 
The coefficient on RetSubs in (7), which is significantly different from zero at the $1 \%$ level, also implies that operating in a country where retail prices are subsidized, which overwhelmingly applies to NOCs and pNOCs, also substantially reduces estimated revenue efficiency. Specifically, the mean retail price in these countries is about $40 \%$ below US retail price. On average, therefore, such subsidies reduce the estimated revenue efficiency for firms headquartered in subsidizing nations by almost $15 \%$ below the average shareholder firm operating in an environment without such subsidies.

The coefficient on Premerge in equation (7) also is significantly different from zero at a better than $1 \%$ level. It implies firms that undertake mergers have a joint DEA efficiency score in the years before they merge that is more than $15 \%$ below the average score of 0.8640 for SOCs. Thus, mergers tend to be efficiency improving.

Finally, at the mean of strictly positive values of VertInt of 1.74, the effect on the estimated DEA score is about 0.027 . However, the coefficient is not significantly different from zero at the $10 \%$ level. This might be attributed to the inclusion of refining capacity among the inputs in the calculation of the DEA scores substantially adjusting for the effects of relatively high participation in downstream markets.

Apart from the efficiency scores $\theta$ the DEA linear program also produces a matrix of coefficients $\lambda$. These give the linear combinations of efficient firms that yield superior performance to each of the inefficient firms in each year. More specifically, the non-zero values of $\lambda_{i j t}$ give the weights on efficient firms $j$ in year $t$ that would result in a composite efficient firm using no more inputs while producing at least as much revenue as inefficient firm $i$.

Figure 2 summarizes the extent to which firms on the efficiency frontier contribute to composite firms that dominate inefficient firms in the same year. The values graphed are $\sum_{i} \lambda_{i j t}$ for each efficient firm $j$ and where $i$ indexes the inefficient firms in year $t$. The sums therefore reflect not only how often each efficient firm appears in a dominating composite firm but also its contribution to such firms. 
Figure 2: Contributions of efficient firms to dominating composite firms

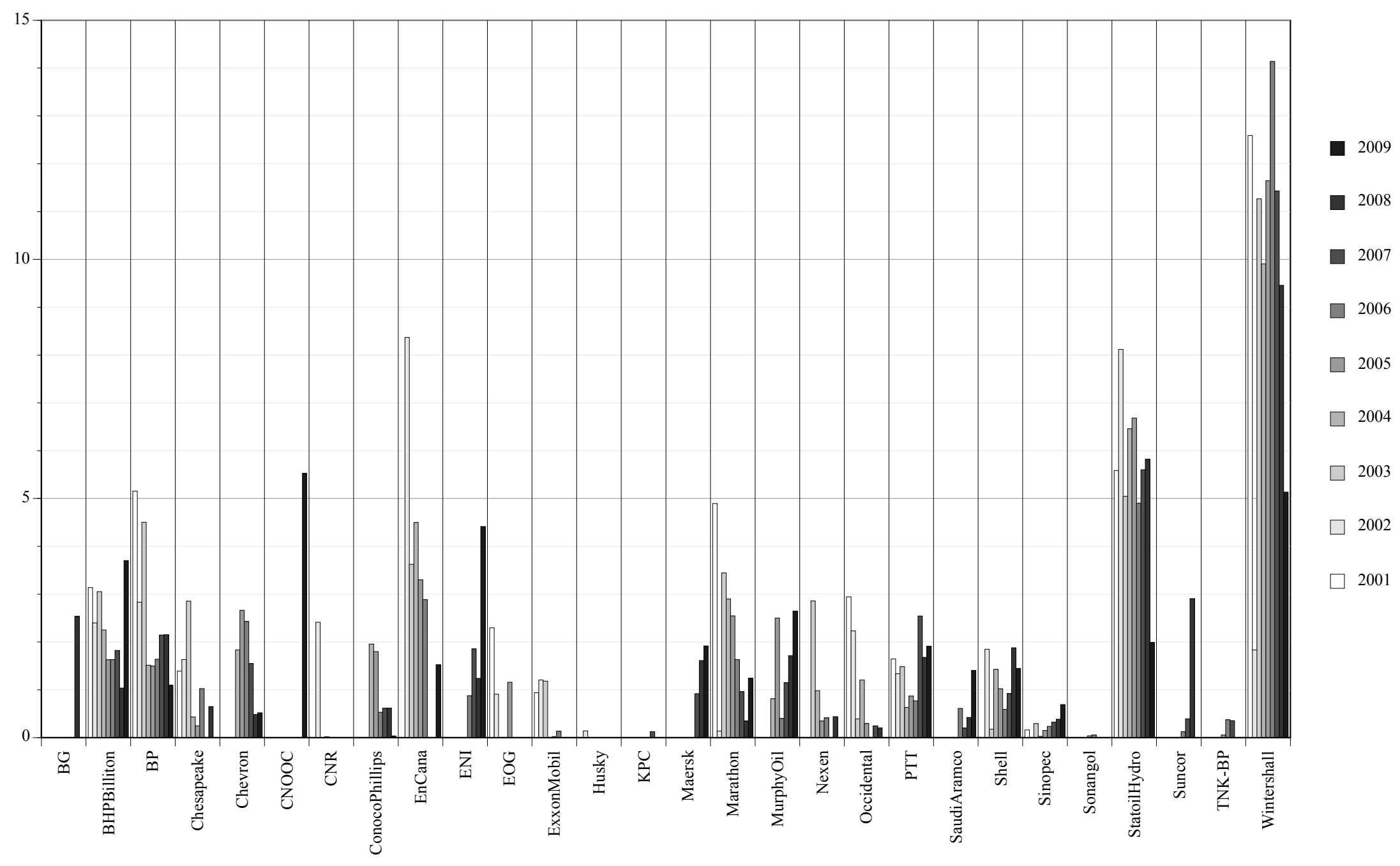


In most years, the German firm Wintershall makes a major contribution to the dominating composite firms on the efficient frontier. Not only is it present in a large number of dominating composite firms. It also frequently has the largest $\lambda$ weight making it the most important firm in the composite. In other words, Wintershall tends to have a similar input composition mix to many inefficient firms in the sample, meaning it may be the most representative model for those inefficient firms to emulate. Other firms that play a prominent role in forming dominating composite firms include StatoilHydro, EnCana, BP, BHPBilliton and Marathon.

Some firms that contribute to dominating composite firms in some years (most especially CNOOC in 2009) do not do so in other years because they are not themselves on the frontier in those years. In other cases, such as ExxonMobil, the firm is on the frontier in every year but does not play prominent role contributing to dominating composite firms perhaps because its input mix differs too substantially from that of the inefficient firms.

\subsection{Malmquist index measures of productivity change}

Instead of comparing firm $i$ with other firms operating in the same year one could ask how efficient firm $i$ would have been had it used $x_{i t-1}$ to produce $y_{i t-1}$ while the comparison firms used year $t$ technologies in year $t-1$. Modifying notation slightly, let $D_{t}\left(y_{i t-1}, x_{i t-1}\right)$ denote the latter quantity and $D_{t-1}\left(y_{i t-1}, x_{i t-1}\right)$ the original DEA measure in year $t-1$. The ratio of these distance functions

$$
M_{i t}^{1}=\frac{D_{t}\left(y_{i t}, x_{i t}\right)}{D_{t}\left(y_{i t-1}, x_{i t-1}\right)}
$$

measures productivity growth in firm $i$ from year $t-1$ to year $t$ viewed from the perspective of the set of technologies available in year $t$.

We could also measure the productivity gain from year $t-1$ to year $t$ from the perspective of the technologies available in year $t-1$. Thus, the DEA measure of firm $i$ efficiency if it had generated revenue $y_{i t}$ from inputs $x_{i t}$ while the comparison firms only had access to year $t-1$ technologies would be written $D_{t-1}\left(y_{i t}, x_{i t}\right)$. The productivity gain from year $t-1$ to year $t$ then also could be measured as: 


$$
M_{i t}^{2}=\frac{D_{t-1}\left(y_{i t}, x_{i t}\right)}{D_{t-1}\left(y_{i t-1}, x_{i t-1}\right)} .
$$

The Malmquist index is then defined as the geometric mean of these two measures:

$$
M=\left[\frac{D_{t}\left(y_{i t}, x_{i t}\right)}{D_{t}\left(y_{i t-1}, x_{i t-1}\right)} \frac{D_{t-1}\left(y_{i t}, x_{i t}\right)}{D_{t-1}\left(y_{i t-1}, x_{i t-1}\right)}\right]^{1 / 2} .
$$

Equation (10) can also be written as the product of two components:

$$
M=\frac{D_{t}\left(y_{i t}, x_{i t}\right)}{D_{t-1}\left(y_{i t-1}, x_{i t-1}\right)}\left[\frac{D_{t-1}\left(y_{i t-1}, x_{i t-1}\right)}{D_{t}\left(y_{i t-1}, x_{i t-1}\right)} \frac{D_{t-1}\left(y_{i t}, x_{i t}\right)}{D_{t}\left(y_{i t}, x_{i t}\right)}\right]^{1 / 2} .
$$

The first ratio (outside the square brackets) is the so-called efficiency change, and measures movements towards the frontier from year $t-1$ to year $t$ by firm $i$. This can be obtained from the annual DEA measures graphed in Figure 1 above.

The first ratio in square brackets in (11) measures the proportional change in the efficient frontier at the data observed for firm $i$ in period $t-1$, while the second ratio measures the change in the frontier at the data observed for firm $i$ in period $t$. The geometric average of these two ratios, called a measure of technical change, thus measures the change in frontier technology between the two periods for the parts of the frontier relevant for firm $i$.

Figure 3 graphs the technical change measures for each firm and pair of successive years. In interpreting Figure 3, it is useful to focus first on the firms that are on the frontier every year, namely Wintershall, Marathon, ExxonMobil, BP, BHPBilliton, StatoilHydro, Sinopec and PTT (Figure 1). These firms will play the major role in shifting the frontier from $t-1$ to $t .{ }^{21}$ Observe that the technical change measure can be written as:

$$
\left[\frac{D_{t-1}\left(y_{i t}, x_{i t}\right) / D_{t}\left(y_{i t-1}, x_{i t-1}\right)}{D_{t}\left(y_{i t}, x_{i t}\right) / D_{t-1}\left(y_{i t-1}, x_{i t-1}\right)}\right]^{1 / 2} .
$$

\footnotetext{
${ }^{21}$ Firms on the frontier in just one of the two successive years will also generally influence the shape of the frontier in that year, but will have no effect on the shape of the frontier in the year they are off it.
} 
Figure 3: Technical change measures relevant for each firm in successive years

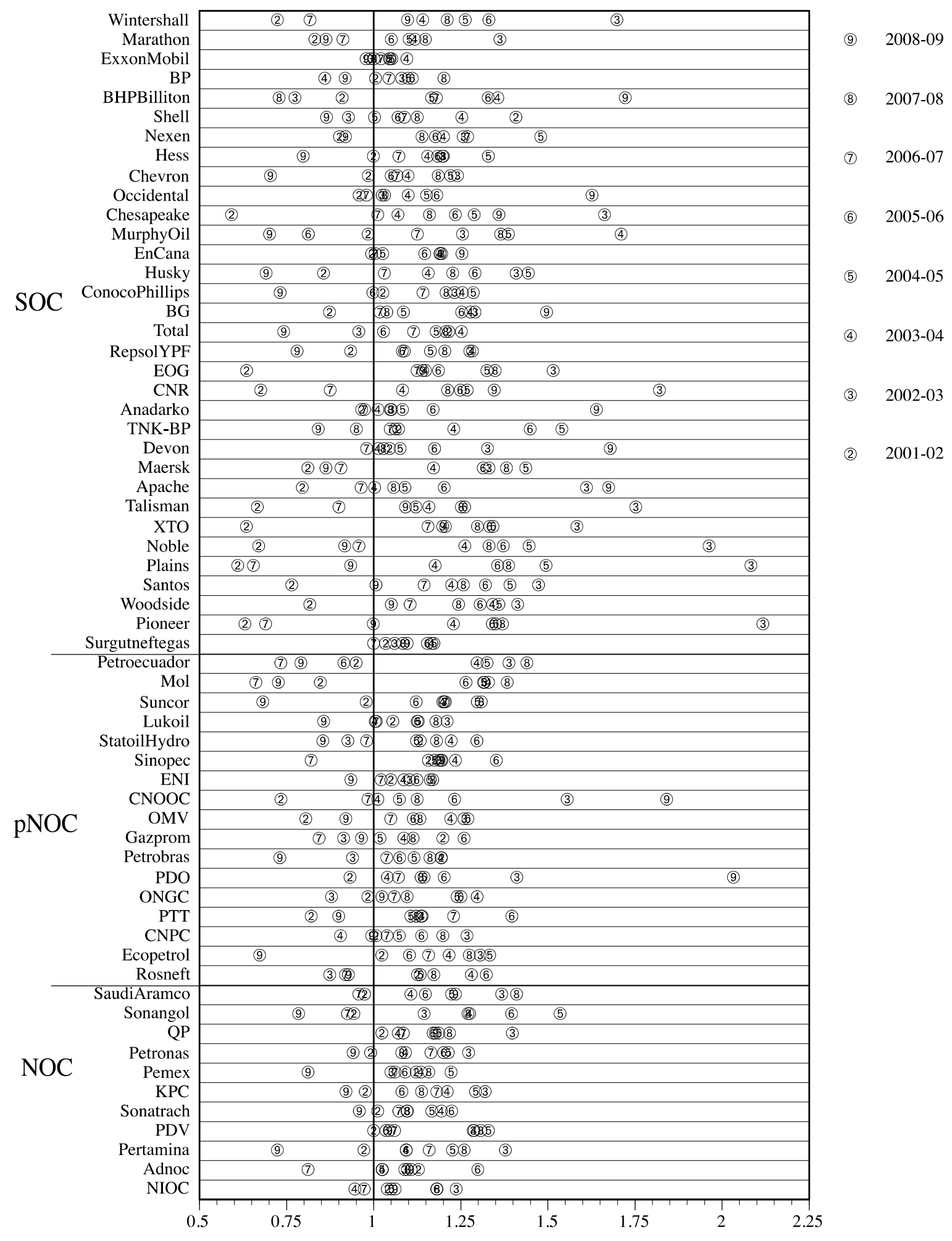


For firms on the frontier in both periods, the ratio in the denominator in (12) will be 1 and the deviation of the technical change measure from 1 will reflect the ratio in the numerator of (12). If the industry is undergoing positive technical progress, ${ }^{22}$ a frontier firm $i$ in year $t-1$ allowed to use $x_{i t}$ to produce $y_{i t}$ when other firms are using year $t-1$ technologies ought to remain on the frontier, that is, we should find $D_{t-1}\left(y_{i t}, x_{i t}\right)=1$. Even if firm $i$ is also on the frontier in year $t$, however, it might not be able to stay there using $x_{i t-1}$ to produce $y_{i t-1}$ when other firms are using year $t$ technologies and we could find $D_{t}\left(y_{i t-1}, x_{i t-1}\right)<1 .^{23}$ Thus, the ratio in the numerator in (12) could exceed 1.

Among the firms that remain on the frontier every year, ExxonMobil stands out as having technical change measures very close to 1 in all years. Thus, ExxonMobil would remain very close to the frontier even if its data were lagged one year relative to the other firms. The technical change measures for BP are only slightly more dispersed than those for ExxonMobil. Among the five SOC firms on the frontier every year, Wintershall and BHPBilliton have the largest dispersions in technical change measures. ${ }^{24}$ Marathon has an intermediate dispersion in technical change measures.

The remaining three firms that are on the frontier every year (StatoilHydro, Sinopec and PTT) are all pNOCs. The dispersions in StatoilHydro and PTT technical change measures are quite similar to those of Marathon. Except for 2006-07, the technical change measures for Sinopec are not much more dispersed than those for ExxonMobil, but their average is substantially above 1 . The implication is that, although Sinopec was on the frontier each year it had to make changes to remain there. If it had not changed its inputs and output it would have fallen below the frontier.

\footnotetext{
${ }^{22}$ Since we are measuring revenue efficiency, higher prices for refined products relative to crude, for example, would result in measured "technological progress" even if "technology" narrowly interpreted is unchanged.

${ }^{23}$ When this happens, the "shape" of the convex hull that describes the production frontier is changing over time.

${ }^{24}$ Since Wintershall and BHPBilliton are often in composite frontier firms dominating the inefficient firms (see Figure 2), they must have input combinations comparable to many other firms. Thus, when their inputs and output are lagged one year it also is easier to find a composite of other firms that can dominate them.
} 
For firms that are not on the frontier in both $t-1$ and $t$, it makes more sense to view the technical change measures in Figure 3 using the original expression on the right hand side of (11), which gives the technical change measure as the product of two ratios. The first ratio measures $D_{t-1}$ relative to $D_{t}$ at $\left(y_{i t-1}, x_{i t-1}\right)$ while the second measures $D_{t-1}$ relative to $D_{t}$ at $\left(y_{i t}, x_{i t}\right)$. If either of these ratios exceeds 1 , the frontier at $t$ shifts out relative to the frontier $t-1$ at the observed input and output proportions of firm $i$ in either $t-1$ or $t .{ }^{25}$

The average of all the technical change measures in Figure 3 across both years and firms is 1.129 , implying that on average the frontier expanded over the decade. ${ }^{26}$ The average technical change measure across firms also exceeded 1 for all pairs of years except from 2001-02, when the average was 0.928. The weaker performance in 2001-02 is evident in Figure 3 where 42 of the technical change scores for 2001-02 are below 1 and those that are above 1 average only 1.103. The frontier shifted in for almost as many firms (32) in 2008-09, but in that case enough firms (including Anadarko, Apache, CNOOC, CNR, Chesapeake, Devon, EnCana, PDO, Pioneer, Plains and SaudiAramco) had technical change scores above 1.3 that the average remains above 1 at 1.069 . The year with the third largest number of technical change scores below 1 was 2006-07, when 21 values were less than 1 and the average was just 1.017. The year with highest average technical change measure was 2002-03, where the measure was below 1 for just eight firms and the average was 1.323. In 2004-05, all technical progress measures exceeded 1, but there were fewer large scores than in 2002-03 and the average was 1.237. In 2003-04 only six, in 2005-06 only four, and in 2007-08 only 7, of the technical progress measures were below 1 and the averages were $1.164,1.130$ and 1.165 respectively.

Figure 3 also shows that the technical change measures for SOCs tend to vary much more than the corresponding measures for pNOCs and especially NOCs. Across all years, the average technical change measure for SOCs is 1.141 compared to 1.123 for NOCs and

\footnotetext{
${ }^{25}$ The ratio of distance measures for firm $i$ in $t-1$ and $t$ equals the ratio of distance to the frontier at $t$ to the distance to the frontier at $t-1$ along a ray determined by firm $i$ input proportions. Thus, a technical change measure exceeding 1 will indicate an expanding frontier at the ray relevant for firm $i$, implying that if the DEA scores remained the same in $t-1$ and $t$ then firm $i$ actually became more productive and thus $M>1$. ${ }^{26}$ This is separate from the results found above that the DEA scores also increased on average, implying that firms got closer to the (shifting) frontier, over the decade.
} 
1.111 for $\mathrm{pNOCs}$, but the standard deviations $(0.181$ for SOCs, 0.151 for $\mathrm{pNOCs}$ and only 0.113 for NOCs) are more different. With the exceptions of CNOOC and PDO in 2008-09, all the large technical change expansions, and the majority of the frontier contractions, occur for SOCs.

We also examined some panel regression relationships for the technical change and overall Malmquist productivity change measures. Since these measures relate to changes from one year to the next we checked for systematic relationships with changes in the ownership, retail subsidy, merger and vertical integration variables we examined as possible explanatory variables for the annual DEA scores.

For the technical change measure, none of the proposed explanatory variables was statistically significantly different from zero at the $10 \%$ level. ${ }^{27}$ A panel regression for the Malmquist total productivity change measures yielded: ${ }^{28}$

$$
\text { Malmq }_{i t}=\underset{(0.018)}{1.163}-\underset{(0.4053)}{0.9929} \Delta \text { Retsubs }_{i t}-\underset{(0.1268)}{0.3677} \text { APremerge }_{i t}
$$

where $\Delta$ is the time difference operator. The coefficients in (13) imply that mergers and a reduction in retail fuel subsidies both raise total productivity. This is consistent with the results for the annual DEA measures in (7) that mergers raise DEA scores, while higher subsidies are associated with lower DEA scores. The fact that $\Delta V e r t I n t$ and none of the $\Delta$ GovSh measures proved significant (and were thus dropped from (13)) is also consistent with the earlier results. In particular, note that although $\mathrm{GovSh}^{+}$was significant in the DEA regression, a partial privatization would change GovSh $=1$ to $1>G o v S h>0$, so the

\footnotetext{
${ }^{27}$ The change in merger variable came closest to being so, with a coefficient of 0.1017 and a $p$-value of 0.129 . This variable would be zero except for the year when a merger occurred when it would take the value -1 . A positive sign of the coefficient would imply that mergers tend to take the "synthetic" premerged firms to a part of the production space where the frontier is closer.

${ }^{28}$ The coefficient on Retsubs has a $p$-value of 0.014 , while that on Premerge has a $p$-value of 0.004 . When we also included changes in GovSh, and VertInt as regressors, the coefficients on Retsubs and PreMerge remained significant at the $3 \%$ and $1 \%$ levels respectively, while neither of the other variables was significant at even the $30 \%$ level. Equation (13) was estimated as a panel regression with random effects. A Hausman test for random versus fixed effects resulted in a chi-square statistic with two degrees of freedom of 2.58 with a $p$-value of 0.275 .
} 
value of $\mathrm{GovSh}^{+}$would not change. Of course, $\Delta G o v S h^{+}$would also be zero for firms that stayed as NOCs or SOCs. ${ }^{29}$ The lack of significance of $\Delta G o v S h$ in (13) therefore supports the conclusion from the DEA measures that partial government ownership has the same effect on efficiency as full government ownership.

\subsection{Stochastic frontier analysis}

The second approach that we use to measure relative revenue efficiency is a parametric stochastic frontier analysis (SFA). ${ }^{30}$ Suppose we can use a single output production function for a cross-section of $N$ firms with $K$ inputs to be given as $y_{i}=f\left(x_{1 i}, \ldots, x_{K i}\right)$, where $i=1,2, \ldots, N$. If the production technology can be represented as Cobb-Douglas, taking natural logarithms of the production function yields the linearized form

$$
\ln y_{i}=\beta_{0}+\sum_{k=1}^{K} \beta_{k} \ln x_{i k}+v_{i}-u_{i}
$$

where $v_{i}$ is a stochastic component reflecting measurement error or omitted variables (such as geological conditions in our example) and $u_{i}$ captures the nonnegative technical efficiency component. Define $\varepsilon_{i}$ as the composed error such that $\varepsilon_{i}=v_{i}-u_{i}$. Once distributions have been proposed for both $v_{i}$ and $u_{i}$, one can estimate (14) using maximum likelihood. ${ }^{31}$ Firm-specific technical efficiency can then be calculated as the expected value of $e^{-u_{i}}$ conditional on $\varepsilon_{i}$. Since $u_{i} \geq 0$, technical efficiency will be bounded between zero and one.

\footnotetext{
${ }^{29}$ Thus, $\Delta G o v S^{+}$would only be non-zero in the very small number of instances where government ownership was eliminated entirely.

${ }^{30}$ We primarily used the program FRONT 4.1 also written by Tim Coelli for the stochastic frontier analysis.

${ }^{31}$ In the analysis presented below, we assume that $v_{i}$ is normally distributed and $u_{i}$ is a truncated normal distribution multiplied by a specific function of time.
} 
Pitt and Lee (1981) extended the maximum likelihood approach for estimating firmspecific technical efficiency to panel data. ${ }^{32}$ The log-linear Cobb-Douglas production function for panel data is

$$
\ln y_{i t}=\beta_{0}+\sum_{k=1}^{K} \beta_{k} \ln x_{i k t}+v_{i t}-u_{i t}
$$

for years $t=1, \ldots, T$ and where the efficiency component $u_{i}$ can depend in a parametric way on time or other measured covariates, but for $u_{i}$ to be identified it cannot have an arbitrary time dependence. ${ }^{33}$ In the simplest specification, we assume:

(i) $v_{i t} \sim N\left(0, \sigma_{v}^{2}\right)$,

(ii) $u_{i t}=e^{-\eta(t-T)} u_{i}$ with $u_{i} \sim N^{+}\left(\mu, \sigma_{u}^{2}\right)$ and $N^{+}$is the truncated-normal distribution,

(iii) $v_{i t}$ and $u_{i}$ are distributed independently of each other and the regressors.

This allows the efficiency of the panel of firms to change over time at the uniform rate $\eta$ per year, although the deviations $u_{i}$ of individual firms from the panel average do not change over time.

In our case, $y_{i t}$ is the revenue of firm $i$ in year $t$, and based on equations (1)-(3), the regressors $x_{k i t}$ are oil and natural gas reserves, distillation capacity, ${ }^{34}$ employees, and oil and natural gas prices. The estimated equation is then given as

$$
\begin{aligned}
\ln R e v_{i t}= & \underset{(0.5504)}{4.3384}+\underset{(0.0421)}{0.3180} \ln E m p_{i t}+\underset{(0.0319)}{0.1919} \ln O i l R s v_{i t}-\underset{(0.0272)}{0.0001 \ln N G R s v_{i t}} \\
& +\underset{(0.0162)}{0.0775} \ln \operatorname{Refcap}_{i t}+\underset{(0.0618)}{0.4150 \ln O i l p_{i t}}+\underset{(0.0550)}{0.4229} \ln N G p_{i t}+v_{i t}-u_{i t}
\end{aligned}
$$

\footnotetext{
${ }^{32}$ Schmidt and Sickles (1984) also proposed using one-sided fixed-effects and random-effects to measure time-invariant producer-specific technical efficiency. See Kumbhakar and Lovell (2000) for a thorough survey of panel stochastic frontier analysis.

${ }^{33}$ The time-varying specifications we shall examine were first proposed by Cornwell, Schmidt and Sickles (1990), and Battese and Coelli (1992, 1995).

${ }^{34}$ Since some firms had no distillation capacity we actually used $\ln (1+$ capacity $)$, which is zero for capacity equal to zero and barely changed from $\ln$ (capacity) when capacity is positive since the average of the strictly positive values is around 1000 (in thousands of barrels per day).
} 
with estimated error structure parameters $\mu=1.506(0.2657), \eta=0.0291(0.0047)$, $\sigma_{u}^{2}=0.4022(0.0888)$ and $\sigma_{v}^{2}=0.0484(0.0031)$.

Since each input should contribute positively to revenue, the coefficients in (16) should all be positive. The results are consistent with this expectation except for the case of natural gas, whose coefficient is negative but not significantly different from zero. The point estimate of $\eta$ also implies, as with the DEA estimates discussed above, that firms in the sample were on average becoming more efficient at generating revenue from the inputs over the period 2001-2009. Finally, the much larger value of $\sigma_{u}^{2}$ relative to $\sigma_{v}^{2}$ implies that more than $89 \%$ of the variation in the composite error term is due to the onesided systematic efficiency differences between the firms rather than statistical noise or measurement error.

Although the DEA and SFA are very different types of measures, they give reasonably similar efficiency rankings for most of the firms. Estimating a panel Tobit regression with firm-specific random effects we obtained

$$
\operatorname{RevEff} f_{i t}^{D E A}=\underset{(0.0507)}{0.4419}+\underset{(0.1884)}{1.5124} \operatorname{RevEff} f_{i t}^{S F A} .
$$

The strong positive correlation between the measures for each firm is also illustrated in Figure 4 . This plots the average of the DEA scores over the nine years against the average $E\left[e^{-u_{i t}} \mid v_{i t}-u_{i t}\right]$ from the stochastic frontier model. The shading of the data points reflects the extent of government ownership.

Figure 4 reveals that the five major SOCs (BP, Chevron, ConocoPhilips, ExxonMobil and Shell) found in the upper right corner of the plot have high DEA and SFA scores. Conversely, the NOCs all tend to have low estimated SFA scores, although their DEA scores are not nearly as concentrated among the low values. 
Figure 4: Average SFA versus average DEA efficiency scores

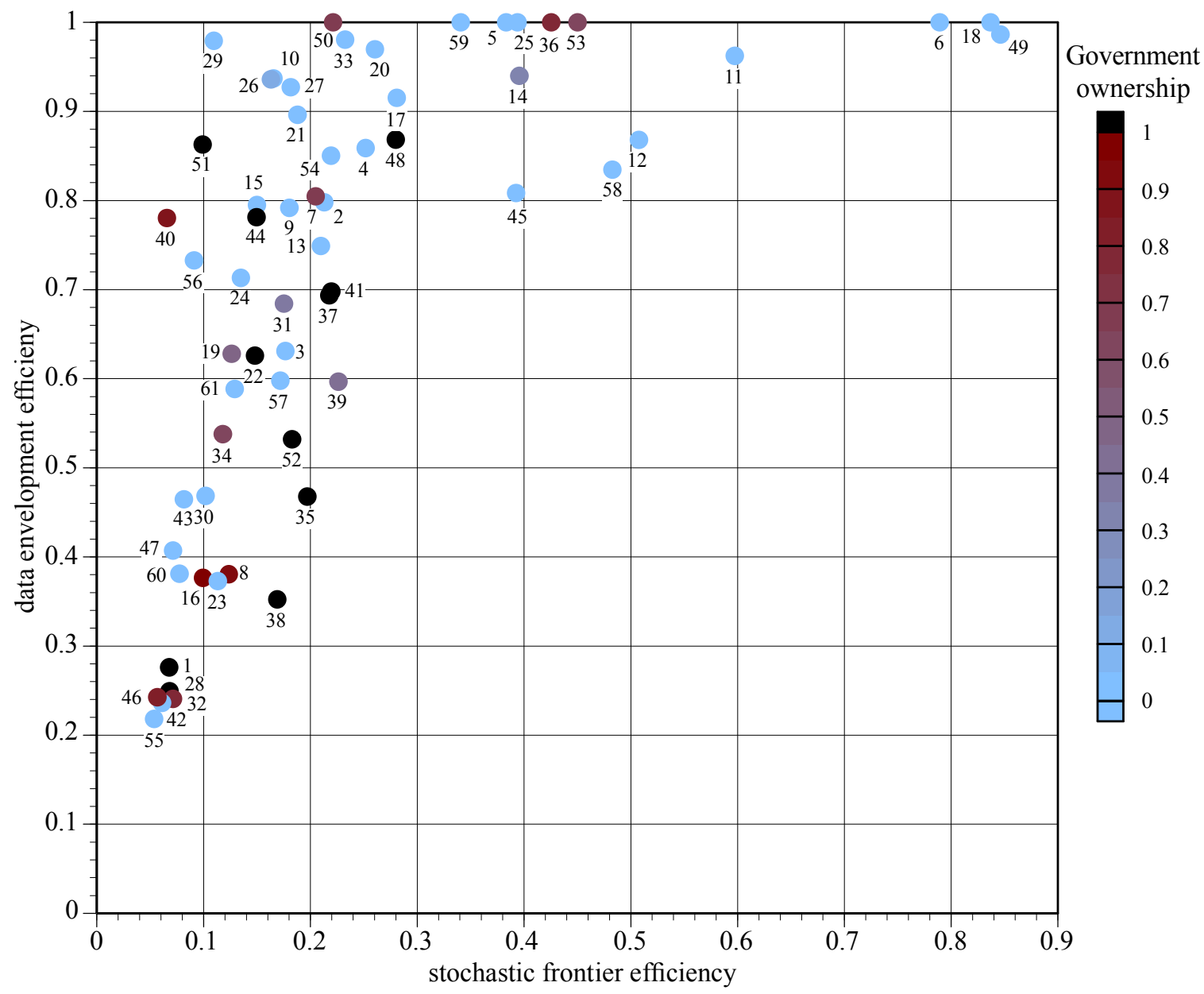

1 Adnoc
2 Anadarko
3 Apache
4 BG
5 BHPBilliton
6 BP
7 CNOOC
8 CNPC
9 CNR
10 Chesapeake
11 Chevron
12 ConocoPhillips
13 Devon
14 ENI
15 EOG
16 Ecopetrol
17 EnCana
18 ExxonMobil
19 Gazprom
20 Hess
21 Husky

$22 \mathrm{KPC}$

23 Lukoil

24 Maersk

25 Marathon

$26 \mathrm{Mol}$

27 MurphyOil

28 NIOC

29 Nexen

30 Noble

31 OMV

32 ONGC

33 Occidental

34 PDO

35 PDV

36 PTT

37 Pemex

38 Pertamina

39 Petrobras

40 Petroecuador

41 Petronas
42 Pioneer

43 Plains

$44 \mathrm{QP}$

45 RepsolYPF

46 Rosneft

47 Santos

48 SaudiAramco

49 Shell

50 Sinopec

51 Sonangol

52 Sonatrach

53 StatoilHydro

54 Suncor

55 Surgutneftegas

56 TNK-BP

57 Talisman

58 Total

59 Wintershall

60 Woodside

61 XTO 
An indication of which components of the DEA inefficiency measures are also present in the SFA measures can be obtained by re-estimating equation (7) with the SFA efficiency score as an additional control variable. Specifically, if a formerly significant explanatory variable is no longer significant when the SFA scores are included, we can conclude that the SFA score accounts for the effects of that variable on the DEA inefficiency measure. The results indicated that the one-sided SFA efficiency error components capture a substantial fraction of the systematic effects of $\mathrm{GovSh}^{+}, \mathrm{GovSh}^{+}$*year, Premerge and RetSubs on DEA efficiency scores. ${ }^{35}$

Some components of the DEA inefficiency scores may not be present in the SFA scores because they could instead affect the estimated revenue function. This is particularly so for the retail subsidy variable, which was calculated as the percentage discount on retail fuel prices below the corresponding US prices, and set to zero when prices were greater than or equal to the US prices. We would expect (1-RetSubs) to multiply the oil price in producing revenue and therefore $\ln (1-$ RetSubs $)$ should be included in the estimated revenue function rather than the error term.

Similarly, a major conclusion of the theoretical analysis of NOC behavior by Hartley and Medlock (2008) was that the relative inefficiency of NOCs is likely to be manifest in substantial over-employment. Equivalently, this should show up as a reduced productivity of labor in NOCs. If this hypothesis is valid we should also expect to find an interaction term between GovSh and $\ln E m p$ in the estimated revenue function (16).

\footnotetext{
${ }^{35}$ The resulting equation was

$$
\begin{aligned}
\operatorname{RevEff}_{i t}^{D E A} & =\underset{(0.0603)}{0.5775}+\underset{(0.1996)}{1.1588} \operatorname{RevEff}_{i t}^{S F A}-\underset{(0.0568)}{0.1168 \text { GovSh }_{i t}^{+}}+\underset{(0.0048)}{0.0092 \text { GovSh }_{i t}^{+} * \text { year }}{ }_{t} \\
& -\underset{(0.1122)}{0.2676 \text { RetSubs }_{i t}}-\underset{(0.0457)}{0.1109 \text { Premerge }_{i t}}+\underset{(0.0106)}{0.0075 \text { VertInt }_{i t}}
\end{aligned}
$$
}

The coefficients of GovSh${ }^{+}$and GovSh${ }^{+}$year are almost halved in value and the $p$-values increase from less than 0.001 to 0.040 and 0.075 respectively. The coefficient of RetSubs decreases by about $17 \%$ (in absolute value) and its $p$-value increases from 0.010 to 0.017 . Similarly, the coefficient of Premerge decreases slightly and its $p$-value increases from 0.003 to 0.015 . The $p$-value for the coefficient of VertInt increases even more, from 0.163 to 0.482 , but the coefficient is not statistically significant in either model. 
With these considerations in mind, we estimated a revised SFA model that included GovShare* $\ln E m p$ and $\ln (1-$ RetSubs $)$ in the estimated revenue function and allowed for a structural model of the one-sided inefficiency component of the error term using the specification of Battese and Coelli (1995). This specification allows the mean of the firmspecific inefficiency measures $u_{i t}$ to depend on firm-specific covariates $z_{l i t}$, where $l=1, \ldots, L$, such that

$$
u_{i t}=z_{i t} \delta+w_{i t} .
$$

The random variable $w_{i t}$ in (18) is a truncated normal distribution with zero mean and variance $\sigma_{w}^{2}$ such that the point of truncation is $-z_{i t} \delta$ that is, $w_{i t} \geq-z_{i t} \delta$. As Battese and Coelli remark, these assumptions are consistent with $u_{i t}$ being a non-negative truncation of the $N\left(z_{i t} \delta, \sigma_{w}^{2}\right)$-distribution. To identify the model, Battese and Coelli assume that the non-efficiency related error component $v_{i t}$ in (15) is iid $N\left(0, \sigma_{v}^{2}\right)$ and independently distributed from the $u_{i t}$. The latter are also assumed to be independently distributed from each other. Maximum likelihood estimates of the parameters of the model were obtained using the program FRONTIER 4.1 (Coelli, 1996b).

We allowed government ownership share, the pre-merger indicator variable and the vertical integration measure as potential $z$ variables. In addition, the strong statistical significance of the time trend coefficient $\eta$ in the basic SFA model, and the significance of the time trend variables in the DEA panel Tobit regression models, suggested that we include time trend or time trend interactions among the set of potential $z$ variables. The best estimated model was:

$$
\begin{aligned}
& \ln R e v_{i t}=\underset{(0.2850)}{1.2441+\underset{(0.0300)}{0.3227} \ln E m p_{i t}}-\underset{(0.0078)}{0.0546 G o v S h_{i t}} * \ln E m p_{i t}+\underset{(0.0320)}{0.1506 \ln O i l R s v_{i t}} \\
& +\underset{(0.0261)}{0.2443 \ln N G R s v_{i t}}+\underset{(0.0134)}{0.1226 \ln \operatorname{Refcap}_{i t}}+\underset{(0.0811)}{0.5281 \ln \text { Oilp }_{i t}}
\end{aligned}
$$

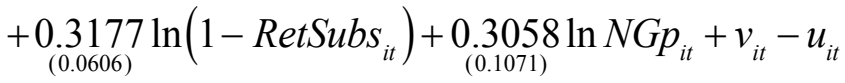

with the auxiliary equation for the one-sided inefficiency error term given by: 


$$
\begin{aligned}
u_{i t} & =\underset{(0.2176)}{0.5612}+\underset{(0.2525)}{0.9471 G^{0}} S_{S h}^{+}-\underset{(0.0365)}{0.1127 G o v S h_{i t}^{+}} * \text { year }_{t} \\
& -\underset{(0.1032)}{0.5555 \text { VertInt }_{i t}}+w_{i t}
\end{aligned}
$$

In addition, the estimated overall variance of the error term $\sigma_{v}^{2}+\sigma_{w}^{2}$ was 0.6658 (with an estimated standard error of 0.0937 ), while the proportion due to the one-sided error was $\gamma=0.9189(0.0227)$.

All the coefficients in (19) except for the one on the natural gas price are significantly different from zero at the 0.0001 level. The natural gas price coefficient has a $p$-value of 0.0043. In the model (20) for the one-sided inefficiency error term, the coefficient on VertInt is significantly different from zero at the 0.0001 level, the coefficient on $\mathrm{GovSh}^{+}$ has a $p$-value of 0.0002 , and the coefficient on $\mathrm{GovSh}^{+}$*year, has a $p$-value of 0.0020 .

Since the indicator for any amount of government ownership GovSh${ }^{+}$appears in (20), ${ }^{36}$ as with the DEA panel Tobit regression models examined previously, any government ownership tends to reduce revenue efficiency. However, the extent of the reduced efficiency measured in (20) tends to decline over time and is completely gone by 2009. Nevertheless, since the actual government ownership share GovSh appears in the revenue frontier (19), the marginal product of labor in a fully government owned firm is around $17 \%$ smaller than in a SOC and this effect does not decline over time. Consistent with the results of Wolf and Pollitt (2008) discussed in the introduction, the fact that actual government share enters the revenue function (19) implies that partial privatization reduces the gap in employment productivity between NOCs and SOCs.

\footnotetext{
${ }^{36}$ We also estimated models where the actual ownership share entered the error term model (20), or the indicator for positive government ownership entered the revenue function (19). These produced less significant values for the corresponding coefficients and a lower maximized log likelihood, but did not greatly affect remaining coefficient estimates. We also estimated models with Premerge in the error term model (20) or interacting with $\ln E m p$ (19). In neither case were the coefficients statistically significantly different from zero at even the $20 \%$ level.
} 
The estimated revenue function (19) also implies that oil prices have a larger effect on revenue than natural gas prices ${ }^{37}$ but natural gas reserves have a larger effect than oil reserves. The latter result may suggest that firms on average tend to hold more excess oil than natural gas reserves. The efficiency differences due to retail price subsidies, like the reduced productivity of labor as a result of government ownership, remain throughout the sample period.

The positive coefficient on refining capacity in the revenue function (19) implies that selling refined products enables the firm to generate more revenue. Even if the firm does not have refining capacity, the negative, and quite large, ${ }^{38}$ coefficient on VertInt (the ratio of liquid product sales to liquids production, both measured in physical terms) in (20) implies that firms with more downstream operations will make more revenue relative to the inputs that have been measured in (19). This result could represent firm heterogeneity rather than measured inefficiencies per se.

\section{Conclusion}

We used two very different methods to examine changes in the revenue efficiency of 61 oil and gas firms over the period 2001-09. The sample included national oil companies (NOCs), partially privatized national oil companies (pNOCs) and shareholder owned oil companies (SOCs). The methods we used were non-parametric data envelopment analysis (DEA) and associated Malmquist measure of annual productivity changes, and a parametric stochastic frontier analysis (SFA).

Despite the very different nature of the methods, they produced similar results. In particular, the two sets of relative inefficiency measures were highly correlated. We also found strong evidence that efficiency of the group of firms increased over the decade, but

\footnotetext{
${ }^{37}$ If the revenue function (19) represents a Cobb-Douglas production function times output prices as hypothesized, we would expect the right hand side to be homogeneous of degree 1 in the nominal prices. Although the coefficients on $\ln$ Oilp and $\ln N G P$ do not sum to 1 , these variables measure the actual output prices with error, so the coefficient estimates may be biased toward zero.

${ }^{38}$ At the mean of the variable of 1.1524 , the effect is around $14 \%$ higher than the constant term in (20).
} 
that NOCs and pNOCs tended to improve at a faster rate. Nevertheless, a gap between the SOCs and the other firms was still present at the end of the decade.

Both methods also showed that retail subsidies were a major source of reduced revenue efficiency for many NOCs and pNOCs. The SFA also revealed that government ownership tends to encourage over-employment, or equivalently a reduced productivity of labor. This effect was reduced by partial privatization. On the other hand, the SFA analysis also revealed an additional residual negative impact of government ownership that was not affected by partial privatization. This latter unidentified source of relative inefficiency tended to disappear over the decade.

There were some subtle differences between the two types of analyses that bear mention. For one, the DEA and Malmquist analyses also found evidence that mergers tended to raise the efficiency of the merging firms, but we did not find a similar effect in the SFA. Secondly, the SFA, but not the DEA, analysis revealed that a larger ratio of product sales to liquids production leads to increased revenue ceteris paribus. This is a plausible result since we did not include any capital assets associated with retail operations among the inputs. It is unclear why the DEA analysis did not reveal as strong an effect from this variable. Perhaps refinery capacity proved a better proxy for downstream operations in the non-parametric DEA than in the parametric SFA.

The Malmquist index analysis found that the lowest technical change measures occurred in 2001-02 and highest two years later in 2003-04, perhaps indicating some "catch-up" from previous periods. Generally, the technical change measures for SOCs were more variable, perhaps suggesting that more innovation occurs among these firms. Such information is not evident from SFA.

The DEA and Malmquist analyses also provided some interesting details on the relative efficiencies and efficiency changes of particular firms over the decade. TNK's efficiency jumped after the formation of TNK-BP in 2003. After being on the frontier in 2005-07, however, it fell back again in 2008 and 2009 after the influence of the Russian partner in the firm increased. The relative efficiency of the Venezuelan NOC also increased from 
2001-04 before falling back below its 2001 value by 2009 . The pNOC PDO from Oman also displays an increasing then decreasing pattern of efficiency changes. The most efficient pNOCs, Statoil-Hydro, Sinopec and PTT, produced DEA scores similar to the most efficient private firms. Several others, especially ENI, CNOOC and Petrobras, also improved substantially over the decade to end up on or close to the frontier in 2009. Saudi Aramco and Sonangol were the standout NOCs.

Among the five large international SOCs, ExxonMobil stood out by not only being on the frontier in every year but also by having an efficiency measure on or close to the frontier even if its inputs and revenue were lagged one year relative to the remaining firms in the sample. Of the five large SOCs, only BP plays a prominent role in forming part of the composite firms that can be shown to dominate the inefficient firms. In that sense, it makes a more feasible firm for the inefficient firms to emulate. The most common member of such dominating composite peers, however, was the German firm Wintershall. Other firms frequently present in such composites included StatoilHydro, EnCana, BHPBilliton and Marathon. Among the few NOCs that appear on the frontier in any year, only SaudiAramco has a noticeable presence in any dominating composite peer firms. Even then, it is a small part of a composite dominating firm that inefficient firms should try to emulate.

Finally, as we noted in the introduction, the evidence supports the notion that the government overseers of NOCs tend to redistribute resource rents toward both domestic consumers and domestic employees of the firm. As a result, as NOCs control more global oil and gas resources it is reasonable to expect that an increasing majority of oil and gas developments will be undertaken with political objectives in mind. This may result in less production and higher prices than would occur under commercial development. The results also support previous findings that even partial privatizations can increase the efficiency of NOCs, presumably by limiting the ability of politicians to interfere with operating decisions and by requiring the firms to adhere to the accounting and other commercial practices of SOCs. 


\section{Bibliography}

Banker, R.D. (1993). "Maximum Likelihood, Consistency and Data Envelopment Analysis: A Statistical Foundation,” Management Science, 39(10): 1256-1273.

Battese, G.E., and T.J. Coelli (1992). "Frontier Production Functions, Technical

Efficiency and Panel Data: With Application to Paddy Farms in India," Journal of Productivity Analysis, 3(1-2): 153-169.

Battese, G.E., and T.J. Coelli (1995). "A Model for Technical Inefficiency Effects in a Stochastic Frontier Production Function for Panel Data," Empirical Economics, $20: 325-332$.

Coelli, T.J. (1996a). "A Guide to DEAP Version 2.1: A Data Envelopment Analysis (Computer) Program”, CEPA Working Paper 96/8, Department of Econometrics, University of New England, Armidale NSW Australia.

Coelli, T.J. (1996b), “A Guide to FRONTIER Version 4.1: A Computer Program for Stochastic Frontier Production and Cost Function Estimation", CEPA Working Paper 96/7, Department of Econometrics, University of New England, Armidale NSW Australia.

Cornwell, C., P. Schmidt, and R.C. Sickles (1990). "Production Froniters with CrossSectional and Time-Series Variation in Efficiency Levels," Journal of Econometrics, 46(1-2): 185-200.

Cooper, W.W. and K. Tone (1997). "Measures of Inefficiency in Data Envelopment Analysis and Stochastic Frontier Estimation," European Journal of Operational Research, 99(1): 72-88.

Desai, A., S.J. Ratick and A. P. Schinnar (2005). "Data envelopment analysis with stochastic variations in data," Socio-Economic Planning Sciences, 39: 147-164.

Eller, Stacy L., Peter R. Hartley and Kenneth B. Medlock III (2011). "Empirical evidence on the operational efficiency of National Oil Companies," Empirical Economics, 40: 623-643. 
Gong, B.H. and R.C. Sickles (1992). "Finite Sample Evidence on the Performance of Stochastic Frontiers and Data Envelopment Analysis Using Panel Data," Journal of Econometrics, 51(1-2): 259-284.

Grosskopf, S. (1996). "Statistical inference and nonparametric efficiency: A selective survey," Journal of Productivity Analysis, 7:161-76.

Hartley, P.R. and K.B. Medlock III (2008). "A Model of the Operation and Development of a National Oil Company," Energy Economics, 30(5): 2459-2485.

Kumbhakar, S.C. and C.A.K. Lovell (2000). Stochastic Frontier Analysis. Cambridge: Cambridge University Press.

Metschies, G.P. (2003-2009). International Fuel Prices. Available at http://www.metschies.com/

Pitt, M. and L.F. Lee (1981). "The Measurement and Sources of Technical Inefficiency in the Indonesian Weaving Industry," Journal of Development Economics, 9:715723.

Ruggiero, J. (2007). “A Comparison of DEA and Stochastic Frontier Model Using Panel Data," International Transactions in Operational Research, 14(3): 259-266.

Schmidt, K.M. (1996). "The Cost and Benefits of Privatization: an Incomplete Contracts Approach," Journal of Law, Economics and Organization, 12(1): 1-24.

Schmidt, P. and R.C. Sickles (1984). "Production Frontiers and Panel Data," Journal of Business and Economic Statistics, 2(4): 367-374.

Tsionas, E. G. (2003). “Combining DEA and stochastic frontier models: An empirical Bayes approach,” European Journal of Operational Research, 147: 499-510. 


\section{ECONOMICS DISCUSSION PAPERS}

2010

\begin{tabular}{|c|c|c|}
\hline $\begin{array}{l}\text { DP } \\
\text { NUMBER }\end{array}$ & AUTHORS & TITLE \\
\hline 10.01 & Hendry, D.F. & $\begin{array}{l}\text { RESEARCH AND THE ACADEMIC: A TALE OF } \\
\text { TWO CULTURES }\end{array}$ \\
\hline 10.02 & McLure, M., Turkington, D. and Weber, E.J. & A CONVERSATION WITH ARNOLD ZELLNER \\
\hline 10.03 & $\begin{array}{l}\text { Butler, D.J., Burbank, V.K. and } \\
\text { Chisholm, J.S. }\end{array}$ & $\begin{array}{l}\text { THE FRAMES BEHIND THE GAMES: PLAYER'S } \\
\text { PERCEPTIONS OF PRISONER'S DILEMMA, } \\
\text { CHICKEN, DICTATOR, AND ULTIMATUM GAMES }\end{array}$ \\
\hline 10.04 & Harris, R.G., Robertson, P.E. and Xu, J.Y. & $\begin{array}{l}\text { THE INTERNATIONAL EFFECTS OF CHINA'S } \\
\text { GROWTH, TRADE AND EDUCATION BOOMS }\end{array}$ \\
\hline 10.05 & Clements, K.W., Mongey, S. and Si, J. & $\begin{array}{l}\text { THE DYNAMICS OF NEW RESOURCE PROJECTS } \\
\text { A PROGRESS REPORT }\end{array}$ \\
\hline 10.06 & Costello, G., Fraser, P. and Groenewold, N. & $\begin{array}{l}\text { HOUSE PRICES, NON-FUNDAMENTAL } \\
\text { COMPONENTS AND INTERSTATE SPILLOVERS: } \\
\text { THE AUSTRALIAN EXPERIENCE }\end{array}$ \\
\hline 10.07 & Clements, $\mathrm{K}$. & $\begin{array}{l}\text { REPORT OF THE } 2009 \text { PHD CONFERENCE IN } \\
\text { ECONOMICS AND BUSINESS }\end{array}$ \\
\hline 10.08 & Robertson, P.E. & $\begin{array}{l}\text { INVESTMENT LED GROWTH IN INDIA: HINDU } \\
\text { FACT OR MYTHOLOGY? }\end{array}$ \\
\hline 10.09 & Fu, D., Wu, Y. and Tang, Y. & $\begin{array}{l}\text { THE EFFECTS OF OWNERSHIP STRUCTURE AND } \\
\text { INDUSTRY CHARACTERISTICS ON EXPORT } \\
\text { PERFORMANCE }\end{array}$ \\
\hline 10.10 & $\mathrm{Wu}, \mathrm{Y}$. & $\begin{array}{l}\text { INNOVATION AND ECONOMIC GROWTH IN } \\
\text { CHINA }\end{array}$ \\
\hline 10.11 & Stephens, B.J. & $\begin{array}{l}\text { THE DETERMINANTS OF LABOUR FORCE } \\
\text { STATUS AMONG INDIGENOUS AUSTRALIANS }\end{array}$ \\
\hline 10.12 & Davies, $\mathrm{M}$. & $\begin{array}{l}\text { FINANCING THE BURRA BURRA MINES, SOUTH } \\
\text { AUSTRALIA: LIQUIDITY PROBLEMS AND } \\
\text { RESOLUTIONS }\end{array}$ \\
\hline 10.13 & Tyers, R. and Zhang, Y. & APPRECIATING THE RENMINBI \\
\hline 10.14 & Clements, K.W., Lan, Y. and Seah, S.P. & $\begin{array}{l}\text { THE BIG MAC INDEX TWO DECADES ON } \\
\text { AN EVALUATION OF BURGERNOMICS }\end{array}$ \\
\hline 10.15 & Robertson, P.E. and Xu, J.Y. & $\begin{array}{l}\text { IN CHINA'S WAKE: } \\
\text { HAS ASIA GAINED FROM CHINA'S GROWTH? }\end{array}$ \\
\hline 10.16 & Clements, K.W. and Izan, H.Y. & $\begin{array}{l}\text { THE PAY PARITY MATRIX: A TOOL FOR } \\
\text { ANALYSING THE STRUCTURE OF PAY }\end{array}$ \\
\hline 10.17 & Gao, G. & WORLD FOOD DEMAND \\
\hline 10.18 & $\mathrm{Wu}, \mathrm{Y}$. & $\begin{array}{l}\text { INDIGENOUS INNOVATION IN CHINA: } \\
\text { IMPLICATIONS FOR SUSTAINABLE GROWTH }\end{array}$ \\
\hline 10.19 & Robertson, P.E. & DECIPHERING THE HINDU GROWTH EPIC \\
\hline 10.20 & Stevens, G. & $\begin{array}{l}\text { RESERVE BANK OF AUSTRALIA-THE ROLE OF } \\
\text { FINANCE }\end{array}$ \\
\hline
\end{tabular}




\begin{tabular}{|l|l|l|}
\hline 10.21 & Widmer, P.K., Zweifel, P. and Farsi, M. & $\begin{array}{l}\text { ACCOUNTING FOR HETEROGENEITY IN THE } \\
\text { MEASUREMENT OF HOSPITAL PERFORMANCE }\end{array}$ \\
\hline 10.22 & McLure, M. & $\begin{array}{l}\text { ASSESSMENTS OF A. C. PIGOU'S FELLOWSHIP } \\
\text { THESES }\end{array}$ \\
\hline 10.23 & $\begin{array}{l}\text { THE ECONOMICS OF NONLINEAR PRICING: } \\
\text { EVIDENCE FROM AIRFARES AND GROCERY } \\
\text { PRICES }\end{array}$ \\
\hline 10.24 & Halperin, D. & $\begin{array}{l}\text { FORECASTING METALS RETURNS: A BAYESIAN } \\
\text { DECISION THEORETIC APPROACH }\end{array}$ \\
\hline 10.25 & Clements, K.W. and Si. J. & $\begin{array}{l}\text { THE INVESTMENT PROJECT PIPELINE: COST } \\
\text { ESCALATION, LEAD-TIME, SUCCESS, FAILURE } \\
\text { AND SPEED }\end{array}$ \\
\hline 10.26 & $\begin{array}{l}\text { Chen, A., Groenewold, N. and Hagger, A.J. } \\
\text { THE REGIONAL ECONOMIC EFFECTS OF A }\end{array}$ \\
\hline 10.27 & $\begin{array}{l}\text { Siddique, A., Selvanathan, E.A. and } \\
\text { Selvanathan, S. }\end{array}$ & $\begin{array}{l}\text { REDUCTION IN CARBON EMISSIONS } \\
\text { EMPIRICAL EVIDENCE FROM BANGLADESH, } \\
\text { INDIA AND SRI LANKA }\end{array}$ \\
\hline
\end{tabular}




\begin{tabular}{|c|c|c|}
\hline \multicolumn{3}{|c|}{$\begin{array}{l}\text { ECONOMICS DISCUSSION PAPERS } \\
2011\end{array}$} \\
\hline $\begin{array}{l}\text { DP } \\
\text { NUMBER }\end{array}$ & AUTHORS & TITLE \\
\hline 11.01 & Robertson, P.E. & $\begin{array}{l}\text { DEEP IMPACT: CHINA AND THE WORLD } \\
\text { ECONOMY }\end{array}$ \\
\hline 11.02 & Kang, C. and Lee, S.H. & $\begin{array}{l}\text { BEING KNOWLEDGEABLE OR SOCIABLE? } \\
\text { DIFFERENCES IN RELATIVE IMPORTANCE OF } \\
\text { COGNITIVE AND NON-COGNITIVE SKILLS }\end{array}$ \\
\hline 11.03 & Turkington, D. & DIFFERENT CONCEPTS OF MATRIX CALCULUS \\
\hline 11.04 & Golley, J. and Tyers, R. & $\begin{array}{l}\text { CONTRASTING GIANTS: DEMOGRAPHIC CHANGE } \\
\text { AND ECONOMIC PERFORMANCE IN CHINA AND } \\
\text { INDIA }\end{array}$ \\
\hline 11.05 & Collins, J., Baer, B. and Weber, E.J. & $\begin{array}{l}\text { ECONOMIC GROWTH AND EVOLUTION: } \\
\text { PARENTAL PREFERENCE FOR QUALITY AND } \\
\text { QUANTITY OF OFFSPRING }\end{array}$ \\
\hline 11.06 & Turkington, D. & $\begin{array}{l}\text { ON THE DIFFERENTIATION OF THE LOG } \\
\text { LIKELIHOOD FUNCTION USING MATRIX } \\
\text { CALCULUS }\end{array}$ \\
\hline 11.07 & Groenewold, N. and Paterson, J.E.H. & $\begin{array}{l}\text { STOCK PRICES AND EXCHANGE RATES IN } \\
\text { AUSTRALIA: ARE COMMODITY PRICES THE } \\
\text { MISSING LINK? }\end{array}$ \\
\hline 11.08 & Chen, A. and Groenewold, N. & $\begin{array}{l}\text { REDUCING REGIONAL DISPARITIES IN CHINA: IS } \\
\text { INVESTMENT ALLOCATION POLICY EFFECTIVE? }\end{array}$ \\
\hline 11.09 & Williams, A., Birch, E. and Hancock, P. & $\begin{array}{l}\text { THE IMPACT OF ON-LINE LECTURE RECORDINGS } \\
\text { ON STUDENT PERFORMANCE }\end{array}$ \\
\hline 11.10 & Pawley, J. and Weber, E.J. & $\begin{array}{l}\text { INVESTMENT AND TECHNICAL PROGRESS IN THE } \\
\text { G7 COUNTRIES AND AUSTRALIA }\end{array}$ \\
\hline 11.11 & Tyers, R. & $\begin{array}{l}\text { AN ELEMENTAL MACROECONOMIC MODEL FOR } \\
\text { APPLIED ANALYSIS AT UNDERGRADUATE LEVEL }\end{array}$ \\
\hline 11.12 & Clements, K.W. and Gao, G. & QUALITY, QUANTITY, SPENDING AND PRICES \\
\hline 11.13 & Tyers, R. and Zhang, Y. & $\begin{array}{l}\text { JAPAN'S ECONOMIC RECOVERY: INSIGHTS FROM } \\
\text { MULTI-REGION DYNAMICS }\end{array}$ \\
\hline 11.14 & McLure, M. & A. C. PIGOU'S REJECTION OF PARETO'S LAW \\
\hline 11.15 & Kristoffersen, I. & $\begin{array}{l}\text { THE SUBJECTIVE WELLBEING SCALE: HOW } \\
\text { REASONABLE IS THE CARDINALITY } \\
\text { ASSUMPTION? }\end{array}$ \\
\hline 11.16 & Clements, K.W., Izan, H.Y. and Lan, Y. & VOLATILITY AND STOCK PRICE INDEXES \\
\hline 11.17 & Parkinson, M. & $\begin{array}{l}\text { SHANN MEMORIAL LECTURE 2011: SUSTAINABLE } \\
\text { WELLBEING - AN ECONOMIC FUTURE FOR } \\
\text { AUSTRALIA }\end{array}$ \\
\hline 11.18 & Chen, A. and Groenewold, N. & $\begin{array}{l}\text { THE NATIONAL AND REGIONAL EFFECTS OF } \\
\text { FISCAL DECENTRALISATION IN CHINA }\end{array}$ \\
\hline 11.19 & Tyers, R. and Corbett, J. & $\begin{array}{l}\text { JAPAN'S ECONOMIC SLOWDOWN AND ITS } \\
\text { GLOBAL IMPLICATIONS: A REVIEW OF THE } \\
\text { ECONOMIC MODELLING }\end{array}$ \\
\hline
\end{tabular}




\begin{tabular}{|l|l|l|}
\hline 11.20 & Wu, Y. & $\begin{array}{l}\text { GAS MARKET INTEGRATION: GLOBAL TRENDS } \\
\text { AND IMPLICATIONS FOR THE EAS REGION }\end{array}$ \\
\hline 11.21 & Fu, D., Wu, Y. and Tang, Y. & $\begin{array}{l}\text { DOES INNOVATION MATTER FOR CHINESE HIGH- } \\
\text { TECH EXPORTS? A FIRM-LEVEL ANALYSIS }\end{array}$ \\
\hline 11.22 & Fu, D. and Wu, Y. & $\begin{array}{l}\text { EXPORT WAGE PREMIUM IN CHINA'S } \\
\text { MANUFACTURING SECTOR: A FIRM LEVEL } \\
\text { ANALYSIS }\end{array}$ \\
\hline 11.23 & Li, B. and Zhang, J. & $\begin{array}{l}\text { SUBSIDIES IN AN ECONOMY WITH ENDOGENOUS } \\
\text { CYCLES OVER NEOCLASSICAL INVESTMENT AND } \\
\text { NEO-SCHUMPETERIAN INNOVATION REGIMES }\end{array}$ \\
\hline 11.24 & Krey, B., Widmer, P.K. and Zweifel, P. & $\begin{array}{l}\text { EFFICIENT PROVISION OF ELECTRICITY FOR THE } \\
\text { UNITED STATES AND SWITZERLAND }\end{array}$ \\
\hline 11.25 & Wu, Y. & $\begin{array}{l}\text { ENERGY INTENSITY AND ITS DETERMINANTS IN } \\
\text { CHINA'S REGIONAL ECONOMIES }\end{array}$ \\
\hline & & \\
\hline
\end{tabular}




\begin{tabular}{|c|c|c|}
\hline \multicolumn{3}{|c|}{$\begin{array}{l}\text { ECONOMICS DISCUSSION PAPERS } \\
2012\end{array}$} \\
\hline $\begin{array}{l}\text { DP } \\
\text { NUMBER }\end{array}$ & AUTHORS & TITLE \\
\hline 12.01 & Clements, K.W., Gao, G., and Simpson, T. & $\begin{array}{l}\text { DISPARITIES IN INCOMES AND PRICES } \\
\text { INTERNATIONALLY }\end{array}$ \\
\hline 12.02 & Tyers, R. & $\begin{array}{l}\text { THE RISE AND ROBUSTNESS OF ECONOMIC } \\
\text { FREEDOM IN CHINA }\end{array}$ \\
\hline 12.03 & Golley, J. and Tyers, R. & $\begin{array}{l}\text { DEMOGRAPHIC DIVIDENDS, DEPENDENCIES } \\
\text { AND ECONOMIC GROWTH IN CHINA AND INDIA }\end{array}$ \\
\hline 12.04 & Tyers, $\mathrm{R}$. & LOOKING INWARD FOR GROWTH \\
\hline 12.05 & Knight, $\mathrm{K}$. and McLure, $\mathrm{M}$. & THE ELUSIVE ARTHUR PIGOU \\
\hline 12.06 & McLure, M. & $\begin{array}{l}\text { ONE HUNDRED YEARS FROM TODAY: A. C. } \\
\text { PIGOU'S WEALTH AND WELFARE }\end{array}$ \\
\hline 12.07 & Khuu, A. and Weber, E.J. & HOW AUSTRALIAN FARMERS DEAL WITH RISK \\
\hline 12.08 & Chen, M. and Clements, K.W. & PATTERNS IN WORLD METALS PRICES \\
\hline 12.09 & Clements, K.W. & UWA ECONOMICS HONOURS \\
\hline 12.10 & Golley, J. and Tyers, R. & $\begin{array}{l}\text { CHINA'S GENDER IMBALANCE AND ITS } \\
\text { ECONOMIC PERFORMANCE }\end{array}$ \\
\hline 12.11 & Weber, E.J. & $\begin{array}{l}\text { AUSTRALIAN FISCAL POLICY IN THE } \\
\text { AFTERMATH OF THE GLOBAL FINANCIAL } \\
\text { CRISIS }\end{array}$ \\
\hline 12.12 & Hartley, P.R. and Medlock III, K.B. & $\begin{array}{l}\text { CHANGES IN THE OPERATIONAL EFFICIENCY } \\
\text { OF NATIONAL OIL COMPANIES }\end{array}$ \\
\hline 12.13 & $\mathrm{Li}, \mathrm{L}$. & $\begin{array}{l}\text { HOW MUCH ARE RESOURCE PROJECTS WORTH? } \\
\text { A CAPITAL MARKET PERSPECTIVE }\end{array}$ \\
\hline 12.14 & Chen, A. and Groenewold, N. & $\begin{array}{l}\text { THE REGIONAL ECONOMIC EFFECTS OF A } \\
\text { REDUCTION IN CARBON EMISSIONS AND AN } \\
\text { EVALUATION OF OFFSETTING POLICIES IN } \\
\text { CHINA }\end{array}$ \\
\hline 12.15 & Collins, J., Baer, B. and Weber, E.J. & $\begin{array}{l}\text { SEXUAL SELECTION, CONSPICUOUS } \\
\text { CONSUMPTION AND ECONOMIC GROWTH }\end{array}$ \\
\hline
\end{tabular}

